\title{
Carbon nanotube filler enhances incinerated thermoplastics-induced cytotoxicity and metabolic disruption in vitro
}

Jayme P. Coyle ${ }^{1 *}$ D, Raymond C. Derk', Tiffany G. Kornberg ${ }^{1,2}$, Dilpreet Singh ${ }^{3}$, Jake Jensen ${ }^{1}$, Sherri Friend ${ }^{1}$, Robert Mercer ${ }^{1}$, Todd A. Stueckle ${ }^{1}$, Philip Demokritou ${ }^{3}$, Yon Rojanasakul ${ }^{2}$ and Liying W. Rojanasakul ${ }^{1}$

\begin{abstract}
Background: Engineered nanomaterials are increasingly being incorporated into synthetic materials as fillers and additives. The potential pathological effects of end-of-lifecycle recycling and disposal of virgin and nano-enabled composites have not been adequately addressed, particularly following incineration. The current investigation aims to characterize the cytotoxicity of incinerated virgin thermoplastics vs. incinerated nano-enabled thermoplastic composites on two in vitro pulmonary models. Ultrafine particles released from thermally decomposed virgin polycarbonate or polyurethane, and their carbon nanotube (CNT)-enabled composites were collected and used for acute in vitro exposure to primary human small airway epithelial cell (pSAEC) and human bronchial epithelial cell (Beas-2B) models. Post-exposure, both cell lines were assessed for cytotoxicity, proliferative capacity, intracellular ROS generation, genotoxicity, and mitochondrial membrane potential.

Results: The treated Beas-2B cells demonstrated significant dose-dependent cellular responses, as well as parent matrix-dependent and CNT-dependent sensitivity. Cytotoxicity, enhancement in reactive oxygen species, and dissipation of $\Delta \psi m$ caused by incinerated polycarbonate were significantly more potent than polyurethane analogues, and CNT filler enhanced the cellular responses compared to the incinerated parent particles. Such effects observed in Beas-2B were generally higher in magnitude compared to PSAEC at treatments examined, which was likely attributable to differences in respective lung cell types.

Conclusions: Whilst the effect of the treatments on the distal respiratory airway epithelia remains limited in interpretation, the current in vitro respiratory bronchial epithelia model demonstrated profound sensitivity to the test particles at depositional doses relevant for occupational cohorts.
\end{abstract}

Keywords: Incinerated thermoplastics, Nano-enabled composites, Polycyclic aromatic hydrocarbons, In vitro, Cytotoxicity

\footnotetext{
*Correspondence: nti2@cdc.gov

'Health Effects Laboratory Division, National Institute for Occupational Safety and Health, Morgantown, WV, USA

Full list of author information is available at the end of the article
}

(C) The Author(s). 2020 Open Access This article is licensed under a Creative Commons Attribution 4.0 International License, which permits use, sharing, adaptation, distribution and reproduction in any medium or format, as long as you give appropriate credit to the original author(s) and the source, provide a link to the Creative Commons licence, and indicate if changes were made. The images or other third party material in this article are included in the article's Creative Commons licence, unless indicated otherwise in a credit line to the material. If material is not included in the article's Creative Commons licence and your intended use is not permitted by statutory regulation or exceeds the permitted use, you will need to obtain permission directly from the copyright holder. To view a copy of this licence, visit http://creativecommons.org/licenses/by/4.0/ The Creative Commons Public Domain Dedication waiver (http://creativecommons.org/publicdomain/zero/1.0/) applies to the data made available in this article, unless otherwise stated in a credit line to the data. 


\section{Background}

Thermoplastics, such as polycarbonate and polyurethane, are ubiquitous in the manufacture of commercial and consumer products due to their relative low cost, optical properties, and mechanical strength. Polycarbonate (PC) is used in automotive parts, construction materials, optical and medical devices, circuitry, and food and beverage packaging. Polyurethane (PU) is used in the automotive industry, high-pressure applications, and consumer products [1-3].

The scope of application in industrial and commercial products for both PC and PU is constantly expanding as new types of composites enabled with carbon nanotube (CNT) are being developed [4, 5], particularly for polycarbonate-CNT (PC-CNT) composites [6]. PC-CNT composites offer favorable attributes, including enhanced mechanical hardness, elastic modulus [7], tensile strength [8], and electrical conductivity [9] compared to parent polycarbonate matrices. The viscoelectric properties of PCmultiwalled CNT composites indicate alterations in the temperature-dependent melting behavior of PC [10], allowing these nano-enabled composites (NECs) to retain hardness over the duration of composite life even in the presence of thermal cycling [11]. PU-CNT composites also have superior physiochemical and mechanical properties compared to parent PU matrices [12, 13], increasing NEC use in commercial and industrial settings. Inclusion of novel NEC thermoplastics in commercial and consumer products can lead to potential exposures throughout the product's lifecycle, including NEC particle release during production, fabrication, and use $[14,15]$ or disposal via incineration [16].

Of the 34.4 million tons of plastics disposed through the municipal solid waste (MSW) stream in the U.S., 5.34 million tons were incinerated for energy recovery [17]. Ever-increasing average tipping fees and decreasing number of operating landfills [18] suggest an increase in MSW being diverted for combustion for energy recovery in the future. Incineration of plastic waste in general results in the formation of volatile organic chemicals (VOCs) in both fly ash and flue gas streams [19, 20]. Though specific types of VOCs generated depends on temperature of combustion, common MSW incinerators $\left(600-950^{\circ} \mathrm{C}\right)$ predominantly generate low- and highmolecular weight polycyclic aromatic hydrocarbons (PAHs) [21-25] through catalytic secondary cyclization [26, 27]. The extent of catalysis depends on the presence and composition of engineered nanomaterial, leading to enhanced $\mathrm{PAH}$ profiles in nanomaterial-rich wastes [28]. The incinerated thermoplastics used in the present study, generated by simulated combustion in the Harvard INEX system, were previously shown to contain detectable amounts of PAHs within the aerosol whose concentrations increased for nano-enabled PU and PC compared to the virgin ones [29].
The exposure to, and potential health effects of, aerosol produced from advanced material NEC combustion is unknown, partially due to the lack of exposure data. Several epidemiological investigations have examined the associations between fine particulate with $\mathrm{PAHs}$ generated from diesel exhaust [30] or from the general urban environment [31-33] with pathological outcomes. PAHs have been purported as an etiological cause of pulmonary carcinogenicity [34] and are traditionally associated with the toxicodynamic properties of diesel exhaust particles (DEP), predominantly through organic extraction studies [35-38].

The potential public health risk of exposure to combustion aerosol particles of novel NECs remains underresearched. The present investigation aims to characterize the potential cytotoxic effects to the airway epithelia of incinerated virgin thermoplastics and incinerated NEC (iNEC) thermoplastic exposure in two histologically distinct regions of the human airway. The bronchus, modeled using the Beas-2B epithelial cell line, is integral for the pathogenesis of asthma and airway resistance [39], especially pathology induced by combustion-derived particulate matter [40]. The distal lung, modeled using primary small airway epithelial cells (pSAECs), is an important region for gas exchange. This investigation augments previous finding using the pSAEC model [41]. Subsequently, partitioning of PAHversus particle-mediated effects was examined by behavioral measures, particularly since PAHs are implicated as contributory to the overall toxicity of combusted carbonaceous particulate including the iNECs.

\section{Results}

\section{Particle characterization}

Stock particles diluted to $1 \mathrm{mg} / \mathrm{mL}$ in $\mathrm{dH}_{2} \mathrm{O}$ were sonicated for electron microscopy analysis for later comparison to intracellularly localized structures in vitro models. Morphological assessment of incinerated thermoplastics by scanning electron microscopy (SEM) and transmission electron microscopy (TEM) showed electron-dense particles (Fig. 1). EDX-assisted elemental compositional analysis of these particles yielded a carbonaceous signature, indicative of PC and PU. iNECs had additional signatures of aluminum and iron (Fig. S1), consistent with associated trace metals found in the CNTs used for composite formulation [29]. We did not attempt to further affirm the presence of nanofiller release in particle suspensions, as this was previously performed [42].

Particle hydrodynamic diameters and zeta potentials were determined using DLS (Table 1). Agglomerate hydrodynamic diameters of test particles ranged from $417 \mathrm{~nm}$ to $1208 \mathrm{~nm}$ with polydispersity indices (PDI) lower than 0.400, indicating good dispersion. Based on these colloidal characteristics, the volume-weighted hydrodynamic diameter of each particle, as well as 


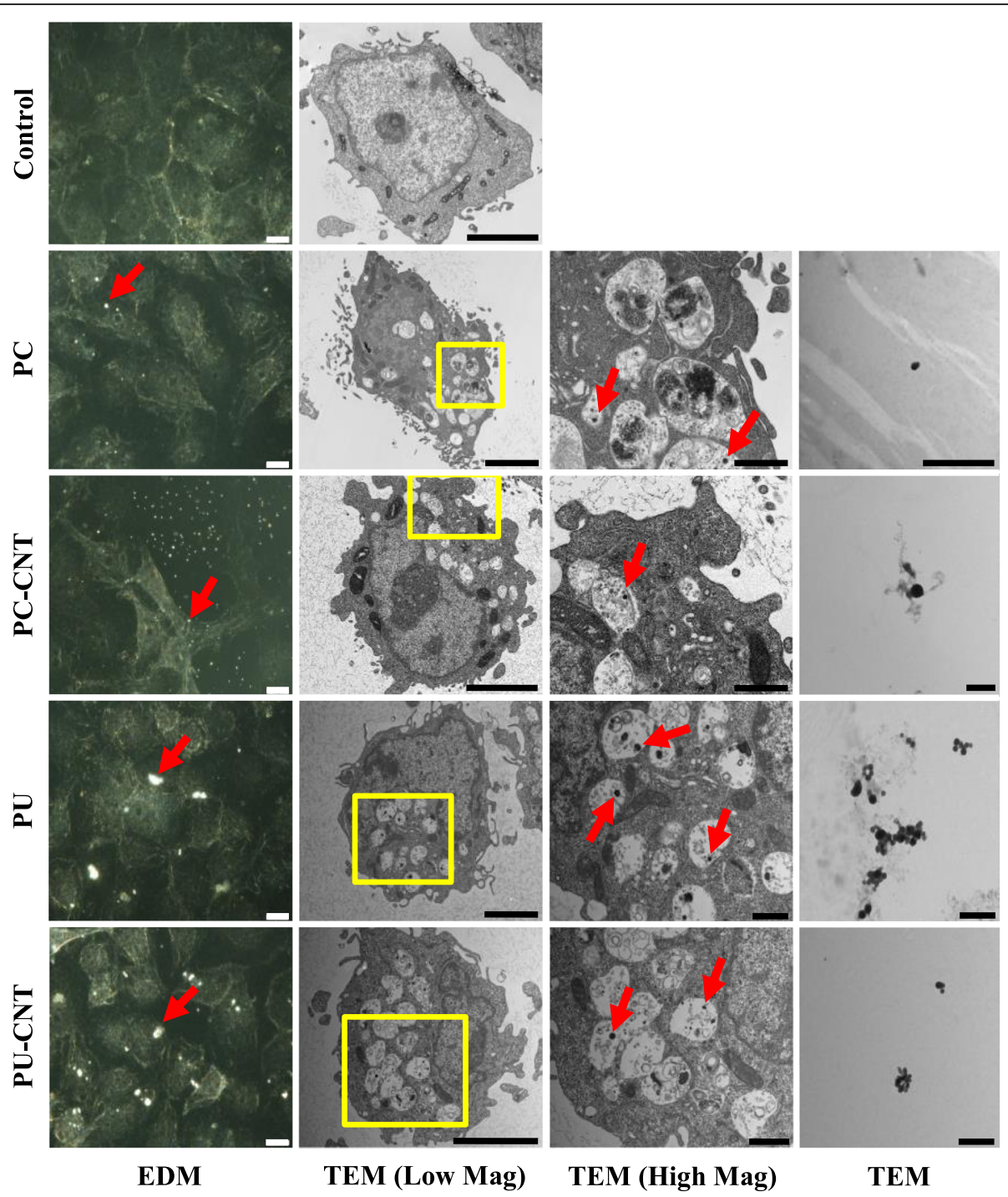

Fig. 1 Microscopic assessment of Beas-2B cells treated with incinerated thermoplastics. Beas-2B treated with $0.6 \mu \mathrm{g} / \mathrm{cm}^{2} \mathrm{or} 1.2 \mu \mathrm{g} / \mathrm{cm}^{2}$ incinerated for $48 \mathrm{~h}$ were visualized via enhanced darkfield microscopy (EDM) or transmission electron microscopy (TEM), respectively. Particles in suspension were also visualized by TEM for comparison against structures identified in Beas-2B cells. Incinerated thermoplastics visualized by EDM are identified by a bright spectral signature (Magnification: 60X, scale bar $=10 \mu \mathrm{m}$ ). Cells treated with incinerated thermoplastics were visualized under low magnification (Scale Bar $=4 \mu \mathrm{m}$ ) and high magnification (Yellow Box denotes region of high magnification, Scale Bar $=1 \mu \mathrm{m}$ ). Particle dispersed in water were prepared and visualized for TEM (Scale Bar $=1 \mu \mathrm{m})$. Endocytosed particles are identified by red arrows in EDM and high magnification TEM images

depositional efficiency [Administered dose translating to deposited dose], were calculated from the Harvard Distorted Grid (DG) model. Particle volume-weighted diameters were generally smaller than incinerated virgin thermoplastics, necessitating higher administered dose loadings for iNECs to attain comparable deposited doses to virgin counterparts. Depositional doses tended to be higher in airway epithelial growth medium (AEGM) than comparable doses in small airway epithelial growth medium (SAGM), requiring higher thermoplastic loadings in SAGM for treating pSAECs with an analogous dose as Beas-2Bs (Table 2). Given the discrepancy in depositional efficiency, we utilized modeled depositional dose as the exposure metric rather than administered dose.

\section{Microscopy}

Stock particles diluted to $1 \mathrm{mg} / \mathrm{mL}$ in $\mathrm{dH}_{2} \mathrm{O}$ were sonicated and subsequently diluted in AEGM and SAGM for in vitro model exposure. Macroscopic localization of the particles showed cell-associated light-scattering diffraction signatures consistent with those of particle-only suspensions (Fig. S2), indicating nano-scale particles reached the cellular microenvironment. TEM examination of intracellular membrane- 
Table 1 Incinerated Thermoplastic Colloidal Characteristics - DLS

\begin{tabular}{lllllll}
\hline Particle & Medium & $\begin{array}{l}\mathrm{d}_{(\mathrm{H}, \mathrm{Z} \text {-avg })} \\
(\mathrm{nm})\end{array}$ & $\mathrm{PDI}$ & $\zeta(\mathrm{mV})$ & $\mathrm{pH}$ & $\sigma(\mathrm{mS} / \mathrm{cm})$ \\
\hline $\mathrm{PC}$ & $\mathrm{dH}_{2} \mathrm{O}$ & 867 & 0.200 & -29.8 & 6.13 & 0.012 \\
& $\mathrm{AEGM}$ & 1208 & 0.140 & -9.73 & 7.41 & 12.3 \\
& $\mathrm{SAGM}$ & 801 & 0.372 & -12.7 & 7.48 & 12.2 \\
PC-CNT & $\mathrm{dH}_{2} \mathrm{O}$ & 541 & 0.048 & -35.5 & 6.31 & 0.010 \\
& $\mathrm{AEGM}$ & 701 & 0.175 & -9.85 & 7.42 & 12.2 \\
& $\mathrm{SAGM}$ & 587 & 0.206 & -12.3 & 7.48 & 11.4 \\
PU & $\mathrm{dH}{ }_{2} \mathrm{O}$ & 836 & 0.209 & -6.97 & 5.34 & 0.014 \\
& $\mathrm{AEGM}$ & 724 & 0.284 & -10.3 & 7.48 & 12.1 \\
& $\mathrm{SAGM}$ & 579 & 0.371 & -10.7 & 7.50 & 11.6 \\
PU-CNT & $\mathrm{dH}{ }_{2} \mathrm{O}$ & 603 & 0.233 & -7.47 & 5.31 & 0.015 \\
& $\mathrm{AEGM}$ & 559 & 0.375 & -9.21 & 7.53 & 12.1 \\
& SAGM & 417 & 0.305 & -11 & 7.52 & 11.4
\end{tabular}

Incinerated thermoplastics were diluted to $0.1 \mathrm{mg} / \mathrm{mL}$ in respective medium and assessed for intensity-based hydrodynamic diameter $\left[\mathrm{d}_{(\mathrm{H}, \mathrm{Z} \text {-avg) }}\right)$, polydispersity index (PDI), zeta potential (द), suspension $\mathrm{pH}$, and suspension conductivity $(\sigma)$

bound vesicles affirmed the presence of intracellularlylocalized test particles (Fig. 1 and Fig. 2). PU/PU-CNT tended to associate with cells to a larger extent than PC/PCCNT analogues at comparable deposited doses in both cell types, though we did not account for detachment of particle-laden cells after the 48-h treatment.

\section{Cytotoxicity}

\section{Beas-2B cell model}

Assessment via propidium-iodide adjusted for cell number (PI-) and WST1 metabolism (Fig. 3a) showed a depositional dose-dependent cytotoxicity of PC/PC-CNT above $1.0 \mu \mathrm{g} / \mathrm{cm}^{2}$ at 24 - and 48 -h post-treatment. Neither PU nor PU-CNT caused cytotoxicity detected by WST1 or PI-. The low-dose profile between the WST

Table 2 Incinerated Thermoplastic Colloidal Characteristics Modeling

\begin{tabular}{lllll}
\hline Particle & Medium & $\rho_{\text {agg }}\left(\mathrm{g} / \mathrm{cm}^{3}\right)$ & $\mathrm{d}_{\text {(Vol-weighted) }}(\mathrm{nm})$ & $\begin{array}{l}\text { Deposition } \\
\text { Efficiency }\end{array}$ \\
\hline PC & AEGM & 1.023 & 1255 & $18.6 \%$ \\
& SAGM & 1.024 & 1288 & $17.4 \%$ \\
PC-CNT & AEGM & 1.023 & 976 & $10.8 \%$ \\
& SAGM & 1.028 & 792 & $8.2 \%$ \\
PU & AEGM & 1.021 & 1092 & $21.8 \%$ \\
& SAGM & 1.025 & 747 & $7.1 \%$ \\
PU-CNT & AEGM & 1.020 & 601 & $9.3 \%$ \\
& SAGM & 1.020 & 551 & $2.1 \%$ \\
\hline
\end{tabular}

DLS measurements in AEGM and SAGM were combined with aggregate density $\left(\rho_{\text {agg }}\right)$ derived from the volumetric centrifugation method, and volume-weighted hydrodynamic diameter $\left(\mathrm{d}_{(\text {Vol-weighted })}\right)$ in the Distorted Grid Model to derive the depositional efficiency of particle sedimentation into the in vitro cellular microenvironment averaged over a $72 \mathrm{~h}$ exposure and PI- measures was markedly different for PC and PCCNT. Treatment with $0.06-0.6 \mu \mathrm{g} / \mathrm{cm}^{2} \mathrm{PC} / \mathrm{PC}-\mathrm{CNT}$ did not result in appreciable reductions in PI--reported cytotoxicity compared to controls but caused paradoxical hyper-stimulatory WST1 metabolism. Characteristic reductions in WST1 metabolism were observed beginning with $1.0 \mu \mathrm{g} / \mathrm{cm}^{2}$, in concordance with observed dose-dependent cell viability reduction reported by PIassessment. The low-dose profiles were also significantly different between $\mathrm{PC}$ and PC-CNT: irrespective of assessment by PI- or WST1 or $\mathrm{ED}_{50}$ (Table 3), PC-CNT was significantly more potent $(1.7-2.0$-fold; $p<0.001)$ compared to PC at 24- and 48-h post-treatment. ED ED $_{50}$ values derived from WST1 were approximately 2-3-fold higher than comparative PI-derived values (Table 3). Of note, potency differences between PC and PC-CNT were not apparent when depositional efficiency between particles was not factored (Fig. S3).

To identify the contribution of particle-associated soluble compounds to the cytotoxicity of incinerated particles, thermoplastic preparations were clarified through a $0.2 \mu \mathrm{m}$ PES filter prior to treatment. Filtration completely abrogated cytotoxicity (Fig. 3b; Table 3), while retaining minimal stimulatory WST1 metabolism, albeit with a substantially reduced maximal response. PC/PC-CNT showed detectable dose-dependent adjusted LDH release above $1 \mu \mathrm{g} / \mathrm{cm}^{2}$ at 24 and $48 \mathrm{~h}$, while PU/PU-CNT showed no LDH release (Fig. 3c), thus confirming PI- measures.

To evaluate mitochondrial membrane potential $\left(\Delta \Psi_{\mathrm{m}}\right)$, JC-1 ratiometric analysis was measured on three deposited doses: a non-cytotoxic dose $\left(0.06 \mu \mathrm{g} / \mathrm{cm}^{2}\right)$, the lowest observable deposited dose observed to induce significant cytotoxicity in PC-CNT-treated Beas-2B cells $\left(0.6 \mu \mathrm{g} / \mathrm{cm}^{2}\right)$, and a significantly cytotoxic dose for both $\mathrm{PC}$ and PC-CNT $\left(1.2 \mu \mathrm{g} / \mathrm{cm}^{2}\right)$. In accordance with PI-, the high dose of PC-CNT caused $\Delta \Psi_{\mathrm{m}}$ depolarization, as did Beas-2B treated with $0.6 \mu \mathrm{g} / \mathrm{cm}^{2}$ (Fig. $3 \mathrm{~d}-\mathrm{e}$ ) that did not otherwise show appreciable cytotoxicity. PU-CNT caused significant $\Delta \Psi_{\mathrm{m}}$ depolarization only at the $1.2 \mu \mathrm{g} /$ $\mathrm{cm}^{2}$ deposited dose. $\Delta \Psi \mathrm{m}$ depolarization was also assessed using a fluorescent-reading plate reader. The trends were conserved between the two reading modalities, though the plate reader tended to overestimate $\Delta \Psi \mathrm{m}$ depolarization (Fig. S4).

\section{pSAE cell model}

Assessment via PI+CN and WST1 metabolism demonstrated significant dose-dependent cytotoxicity due to $\mathrm{PC} / \mathrm{PC}-\mathrm{CNT}$ and coincided with increases in LDH membrane permeability (Fig. 4a-c). Compared to Beas-2B cells, particle-induced WST1 hyperstimulatory metabolism in pSAECs was blunted, remaining below $130 \%$ of controls (Fig. 4b). Measurement via PI- also reported 

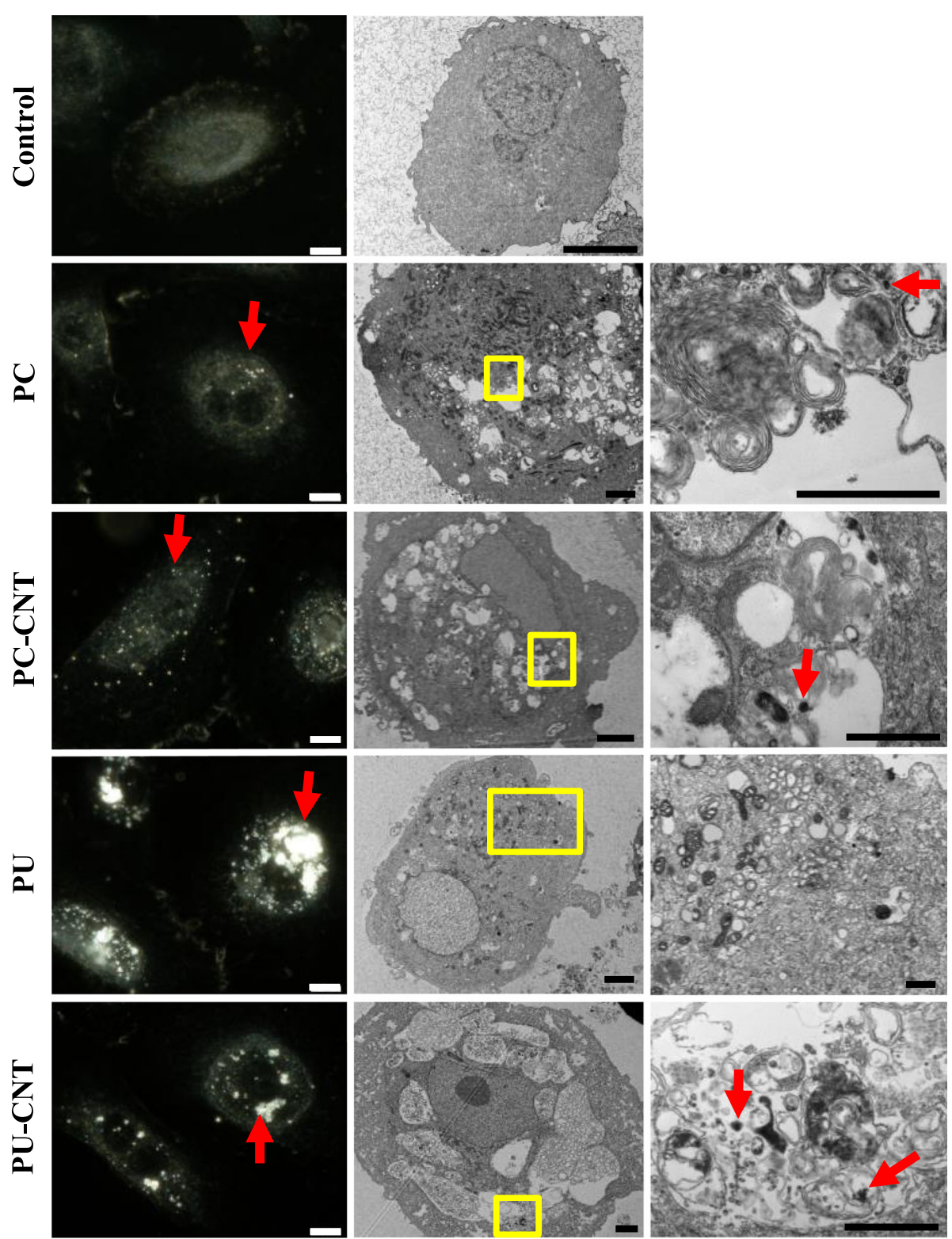

EDM

TEM (Low Mag)

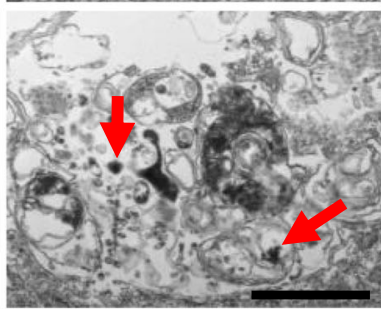

TEM (High Mag)

Fig. 2 Microscopic assessment of pSAECs treated with incinerated thermoplastics. pSAECs treated with $0.6 \mu \mathrm{g} / \mathrm{cm}^{2}$ or $1.2 \mu \mathrm{g} / \mathrm{cm}^{2}$ incinerated for $48 \mathrm{~h}$ were visualized via enhanced darkfield microscopy (EDM) or transmission electron microscopy (TEM), respectively. Particles in suspension were also visualized by TEM (Fig. 1) for comparison against structures identified in PSAECs. Incinerated thermoplastics visualized by EDM are identified by a bright spectral signature (Magnification: 60X, scale bar $=10 \mu \mathrm{m}$ ). Cells treated with incinerated thermoplastics were visualized under low magnification (Scale Bar $=4 \mu \mathrm{m}$ ) and high magnification (Yellow Box denotes region of high magnification, Scale Bar $=1 \mu \mathrm{m}$ ). Endocytosed particles are identified by Red arrows

dose-dependent cytotoxicity of PU/PU-CNT that was not observed by WST1 assessments. Cytotoxic potency values derived from WST1 metabolism and PI- are shown in Table 4. The discrepancy between PI- versus WST1 was determined to be false positivity in live-cell imaging due to co-localization of cellular nuclei and fluorescently-active perinuclear aggregates of endocytosed PU/PU-CNT. pSAECs treated with $1.2 \mu \mathrm{g} / \mathrm{cm}^{2}$ of
PC-CNT and PU-CNT demonstrated significant reductions in $\Delta \Psi_{\mathrm{m}} 24 \mathrm{~h}$ post exposure (Fig. $4 \mathrm{~d}$-e). B[a] P alone paradoxically increased pSAEC $\Delta \Psi_{\mathrm{m}}$ compared to DMSO-treated controls.

\section{CYP1 metabolism and WST1}

It is well known that incineration of thermoplastic matrices produces an array of low- and high-molecular 


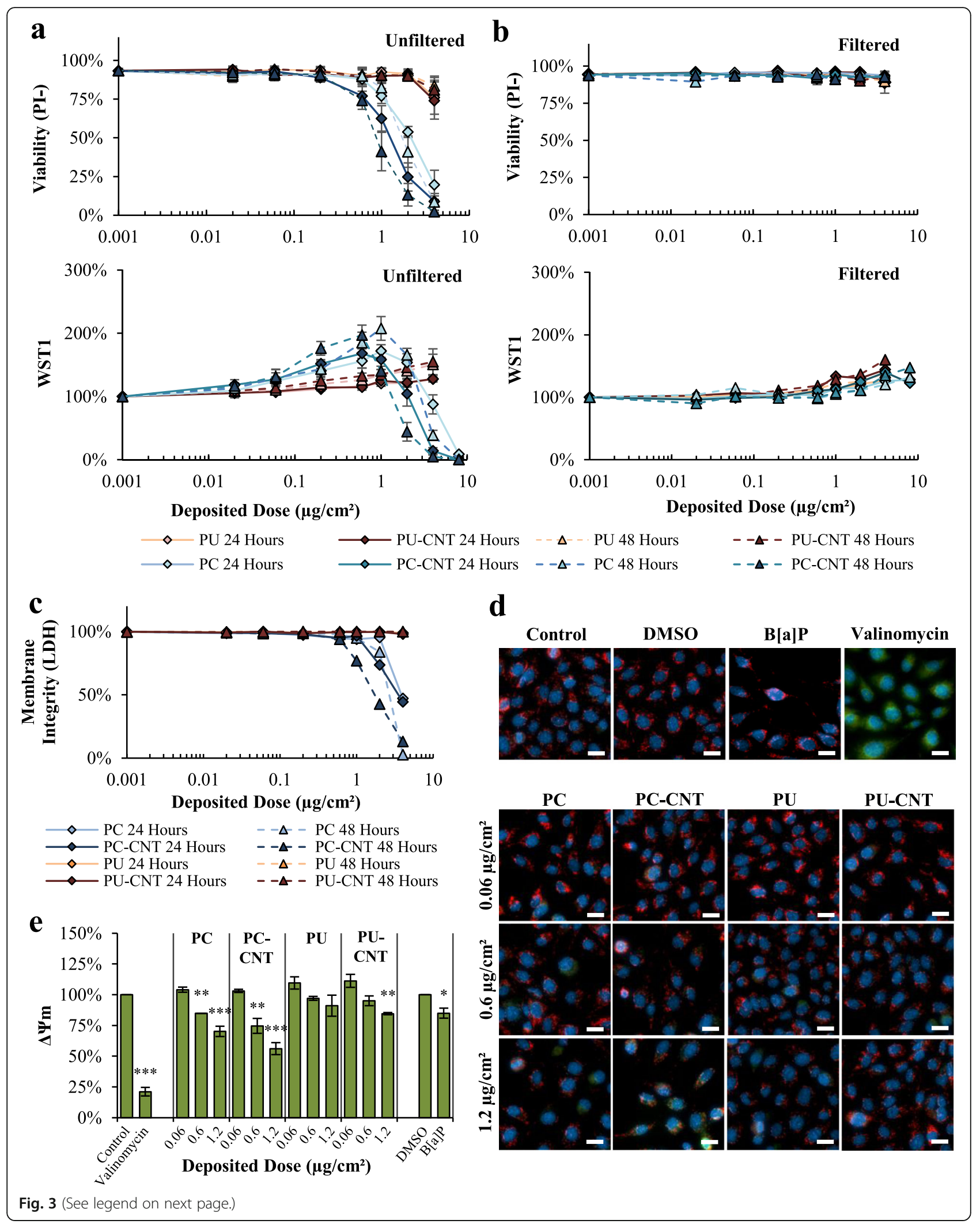


(See figure on previous page.)

Fig. 3 Cytotoxicity assessment of incinerated thermoplastics in Beas-2B Cells. a Dose-response curves to graded depositional doses of incinerated thermoplastics reported by live-cell imaging and WST1 reduction for particle containing suspensions. $\mathbf{b}$ Analogous dose-responses via live-cell imaging and WST1, except particle suspensions were filtered through a $0.2 \mu \mathrm{m}$ pore to devoid treatments of particles, leaving only particle- associated leachables in AEGM. $\mathbf{c}$ Interference-adjusted LDH release 24 and $48 \mathrm{~h}$ after exposure to depositional doses used in live-cell imaging assessments. $\mathbf{d}$-e Representative images of JC-1-reported $\Delta \psi \mathrm{m}$ measurement $24 \mathrm{~h}$ after exposure; scale bars $=20 \mu \mathrm{m}$. As a comparison, $0.5 \mu \mathrm{M}$ B[a]P served as a representative PAH to compare to particle treatments; $10 \mu \mathrm{M}$ valinomycin served as a positive control for $\Delta \psi \mathrm{m}$ dissipation. e Quantitative metrics of images analyzed are presented with statistical comparisons. Point estimates are the arithmetic mean of $2-4$ independent experiments; error bars indicate standard error of the mean (SEM); ${ }^{*} p<0.05,{ }^{* *} p<0.01,{ }^{* * *} p<0.001$ compared to respective controls. Images taken at 40X

weight PAHs $[19,20]$, as was confirmed in a previous investigation using the simulated combustion system used to generate the particles used in the current investigation [29]. AhR-mediated CYP1 bioactivation by B[a]P has been shown to cause stable DNA adduct formation in $\mathrm{B}[\mathrm{a}] \mathrm{P}$-treated Beas-2B cells, leading to genotoxicity and mutagenesis [43]. To ascertain bioavailability of particle-associated PAHs, CYP1 activity was measured as a proxy of AhR activation and subsequent transcriptional machinery for xenobiotic responsive element (XRE). All thermoplastics caused enhanced CYP1 activity at sub-cytotoxic doses, with the largest maximal effect found in Beas-2B treated with $\mathrm{PC}$ and $\mathrm{PC}-\mathrm{CNT}$

Table 3 Beas-2B Cytotoxicity Summarization

\begin{tabular}{|c|c|c|c|c|c|c|}
\hline \multirow{2}{*}{$\begin{array}{l}\text { Filter } \\
\text { Status }\end{array}$} & \multirow[t]{2}{*}{ Time } & \multirow[t]{2}{*}{ Treatment } & \multicolumn{2}{|c|}{$\mathrm{ED}_{50}\left(\mu \mathrm{g} / \mathrm{cm}^{2}\right)$} & \multicolumn{2}{|c|}{ Potency $\mathrm{ED}_{50 \mathrm{P}} / \mathrm{ED}_{50 \mathrm{CNT}}$} \\
\hline & & & $\overline{\mathrm{Pl}}$ & WST1 & $\mathrm{Pl}-$ & WST1 \\
\hline \multirow[t]{8}{*}{ Unfiltered } & 24 & $P C$ & 2.28 & 5.34 & $1.70^{* * *}$ & $1.92^{* * *}$ \\
\hline & 24 & PC-CNT & 1.34 & 2.78 & & \\
\hline & 24 & PU & $>4.0$ & $>4.0$ & N.D. & N.D. \\
\hline & 24 & PU-CNT & $>4.0$ & $>4.0$ & & \\
\hline & 48 & $P C$ & 1.90 & 3.52 & $1.98^{* * *}$ & $1.86^{* * *}$ \\
\hline & 48 & PC-CNT & 0.96 & 1.89 & & \\
\hline & 48 & PU & $>4.0$ & $>4.0$ & N.D. & N.D. \\
\hline & 48 & PU-CNT & $>4.0$ & $>4.0$ & & \\
\hline \multirow[t]{8}{*}{ Filtered } & 24 & PC & $>4.0$ & $>8.0$ & N.D. & N.D. \\
\hline & 24 & PC-CNT & $>4.0$ & $>8.0$ & & \\
\hline & 24 & PU & $>4.0$ & $>4.0$ & N.D. & N.D. \\
\hline & 24 & PU-CNT & $>4.0$ & $>4.0$ & & \\
\hline & 48 & PC & $>4.0$ & $>8.0$ & N.D. & N.D. \\
\hline & 48 & PC-CNT & $>4.0$ & $>8.0$ & & \\
\hline & 48 & PU & $>4.0$ & $>4.0$ & N.D. & N.D. \\
\hline & 48 & PU-CNT & $>4.0$ & $>4.0$ & & \\
\hline
\end{tabular}

PI- - Cytotoxicity derived from live-cell imaging

WST1 - Cytotoxicity derived from the WST1 method

$\mathrm{ED}_{50}$ - Modeled deposited dose causing $50 \%$ of reported cytotoxicity compared to untreated controls

Potency $\mathrm{ED}_{50 \mathrm{p}} / \mathrm{ED}_{50 \mathrm{CNT}}$ - Relative deposited dose causing $50 \%$ of cytotoxicity among pristine incinerated thermoplastic $\left(E_{50 \mathrm{p}}\right)$ compared to CNT-containing analog $\left(E_{50 \mathrm{CNT}}\right)$ at the same time point. Potency comparisons across time points were not made

N.D. $\mathrm{ED}_{50 \mathrm{p}} / \mathrm{ED}_{50 \mathrm{CNT}}$ Potency value could not be determined

${ }^{* * *} p<0.001$ of compared to pristine incinerated thermoplastic at the same time point peaking at $0.6 \mu \mathrm{g} / \mathrm{cm}^{2}$ (420\% of controls) and $0.2 \mu \mathrm{g} / \mathrm{cm}^{2}$ (480\% of controls), respectively. PU and PU-CNT elicited induction of CYP1 activity, albeit with lower effective maxima compared to $\mathrm{PC} / \mathrm{PC}-\mathrm{CNT}$ analogues (Fig. 5a). CYP1 activity in pSAECs treated with the test particles was enhanced, except for PC-CNT that remained approximately at control levels (Fig. 4f).

$\mathrm{B}[\mathrm{a}] \mathrm{P}$ treatment for $48 \mathrm{~h}$ was effective in inducing significant CYP1 activity in Beas-2B cells (Fig. 5b), even though there was no increase in CYP1 metabolism in pSAECs (Fig. 4g). These results suggest incinerated thermoplastic particles contained bioavailable PAHs that translated to enhanced xenobiotic response metabolic activity in Beas-2B cells in congruence with previous observations [44]. B[a]P also caused a significant reduction in PI- viability (Fig. 5c). Since the integrated PImeasure used to evaluate cytotoxicity accounts for both proliferation (cell number) and membrane permeability (PI positivity), the relative contribution of membrane permeability to the overall PI- estimate was not significantly different than untreated controls (3-5\% PI+), indicating $\mathrm{B}[\mathrm{a}] \mathrm{P}$ cytotoxicity was driven by inhibition of cellular proliferation, rather than lytic cytotoxicity. This interpretation was verified by the lack of extracellular $\mathrm{LDH}$ post-exposure of $\mathrm{B}[\mathrm{a}] \mathrm{P}$ (Fig. $5 \mathrm{~d}$ ) in accordance with previous findings $[45,46]$.

To examine whether hyperstimulatory WST1 metabolism was associated with CYP1 metabolic competency, we employed the CYP1/AhR inhibitor $\alpha$ NF [47] and the specific AhR inhibitor $\mathrm{CH} 223191$ [48] to assess their effects on $\mathrm{B}[\mathrm{a}] \mathrm{P}$ - and $\mathrm{PC} / \mathrm{PC}-\mathrm{CNT}$-treated Beas-2B cells. Neither $\alpha$ NF nor $\mathrm{CH} 223191$ caused cytotoxicity or inhibited proliferation at the tested concentrations (Fig. 5e). Pre-treatment with $10 \mu \mathrm{M} \alpha \mathrm{NF}$ alone or in combination with $5 \mu \mathrm{M}$ of the AhR inhibitor $\mathrm{CH} 223191$ reversed hyper-stimulated WST1 metabolism and attenuated B[a]P-induced $\Delta \Psi_{\mathrm{m}}$ depolarization (Fig. 5f). However, neither $\alpha \mathrm{NF}$ alone nor in combination with $\mathrm{CH} 223191$ reversed PC- or PC-CNT-induced WST1 stimulatory metabolism or $\Delta \Psi_{\mathrm{m}}$ depolarization (Fig. 5f). As rescue was not attained through pharmacological inhibition, PC/ PC-CNT particle induced cytotoxic effect in Beas-2B cell seems not to depend on PC/PC-CNT-associated PAHs. While the observation of WST1 hyperstimulation in the 


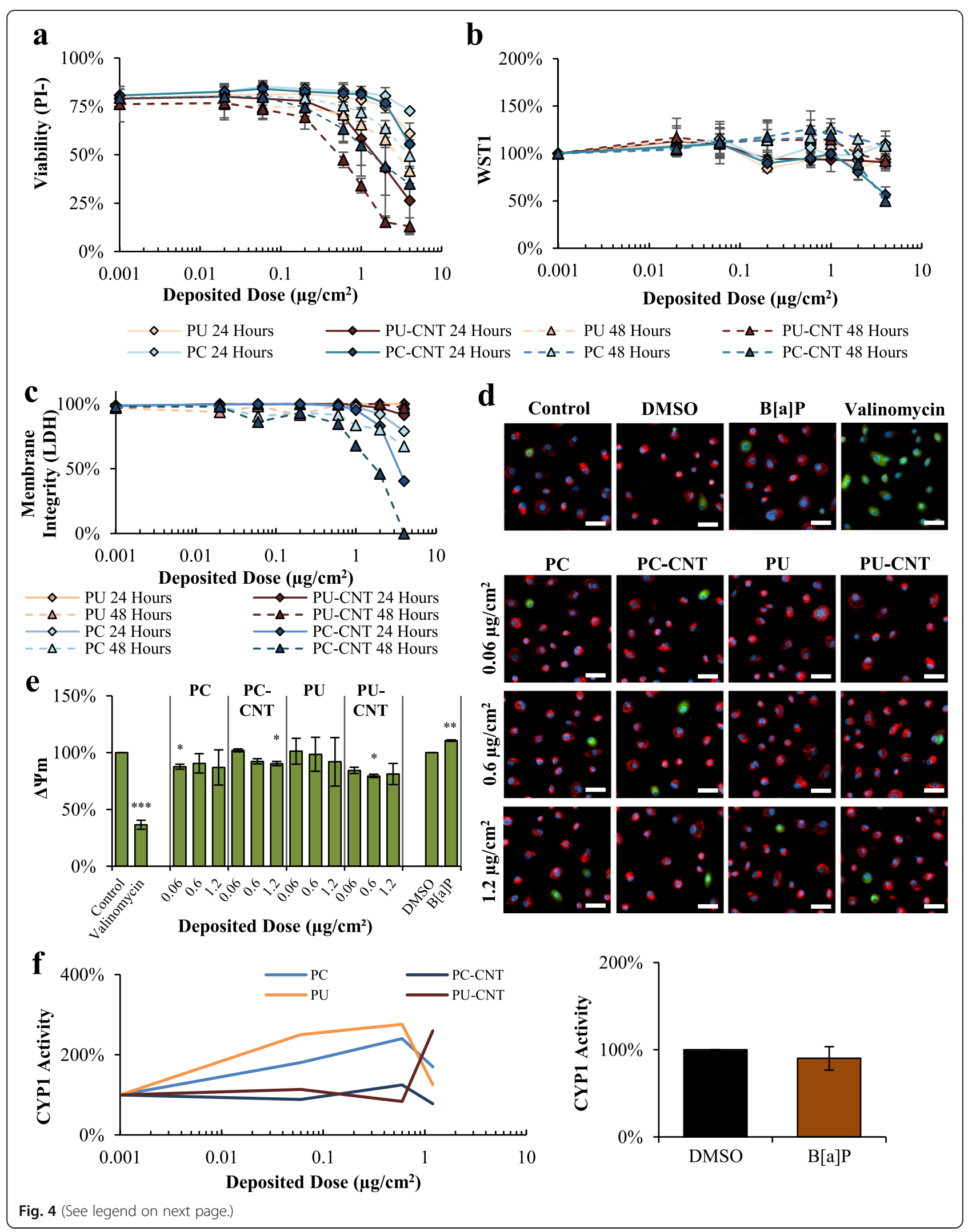


(See figure on previous page.)

Fig. 4 Cytotoxicity assessment of incinerated thermoplastics in pSAECs. a-b Dose-response curves to graded depositional doses of incinerated thermoplastics reported by live-cell imaging and WST1 reduction for particle containing suspensions. c Interference-adjusted LDH release 24 and $48 \mathrm{~h}$ after exposure to depositional doses used in live-cell imaging assessments. d-e Representative images of JC-1-reported $\Delta \psi \mathrm{m}$ measurement $24 \mathrm{~h}$ after exposure; scale bars $=50 \mu \mathrm{m}$. As a comparison, $0.5 \mu \mathrm{M} \mathrm{B[a]P}$ served as a representative PAH to compare to particle treatments; $10 \mu \mathrm{M}$ valinomycin served as a positive control for $\Delta \psi \mathrm{m}$ dissipation. e Quantitative metrics of images analyzed are presented with statistical comparisons. $\mathbf{f}-\mathbf{g}$ pSAECs were assessed for CYP1 activity $48 \mathrm{~h}$ post exposure to incinerated thermoplastics and $0.5 \mu \mathrm{M}$ B[a]P. Point estimates are the arithmetic mean of 2 independent experiments; error bars indicate standard error of the mean (SEM); ${ }^{*} p<0.05$, ${ }^{* *} p<0.01$, compared to respective controls. Images taken at $20 \mathrm{X}$

presence of $\mathrm{PAH}$-associated exposures in Beas-2B is consistent with previous findings of diesel exhaust particle extract-exposed Beas-2B cells [35]. Despite such an observation, that study did attempt to elucidate the source or implications of hyperstimulated WST1 metabolism. To examine if particle uptake was necessary for inducing cytotoxic injury, we employed the actin inhibitor cytochalasin D. Cytochalasin D alone significantly inhibited Beas2B proliferation, as reported by WST1 metabolism, without significant induction of membrane permeability (Fig. 5e) in accordance with previous findings [49]. Upon co-treatment, $0.5 \mu \mathrm{g} / \mathrm{mL}$ cytochalasin D only partially reversed PC/PC-CNT-induced $\Delta \Psi_{\mathrm{m}}$ depolarization (Fig. 5f).

\section{Cell cycle and genotoxicity}

Since the current understanding presumes desorption of particle-adsorbed PAHs leads to genotoxicity [50, 51], we hypothesized particle-adsorbed PAHs would be bioavailable to cause activation of AhR-mediated XREassociated machinery in Beas-2B cells, resulting in genotoxicity [52-55] and partially accounting for reductions

Table 4 pSAEC Cytotoxicity Summarization

\begin{tabular}{|c|c|c|c|c|c|c|}
\hline \multirow{2}{*}{$\begin{array}{l}\text { Filter } \\
\text { Status }\end{array}$} & \multirow[t]{2}{*}{ Time } & \multirow[t]{2}{*}{ Treatment } & \multicolumn{2}{|c|}{$\mathrm{ED}_{50}\left(\mu \mathrm{g} / \mathrm{cm}^{2}\right)$} & \multicolumn{2}{|c|}{$\mathrm{ED}_{50 \mathrm{P}} / \mathrm{ED}_{50 \mathrm{CNT}}$ Potency } \\
\hline & & & $\mathrm{Pl}-$ & WST1 & $\mathrm{Pl}-$ & WST1 \\
\hline \multirow[t]{8}{*}{ Unfiltered } & 24 & PC & $>4.0$ & $>4.0$ & N.D. & N.D. \\
\hline & 24 & PC-CNT & $>4.0$ & $>4.0$ & & \\
\hline & 24 & PU & $>4.0$ & $>4.0$ & N.D. & N.D. \\
\hline & 24 & PU-CNT & 2.21 & $>4.0$ & & \\
\hline & 48 & PC & $>4.0$ & $>4.0$ & N.D. & N.D. \\
\hline & 48 & PC-CNT & 2.73 & 3.49 & & \\
\hline & 48 & PU & $>4.0$ & $>4.0$ & N.D. & N.D. \\
\hline & 48 & PU-CNT & 0.83 & $>4.0$ & & \\
\hline
\end{tabular}

PI- - Cytotoxicity derived from live-cell imaging

WST1 - Cytotoxicity derived from the WST1 method

$\mathrm{ED}_{50}$ - Modeled deposited dose causing $50 \%$ of reported cytotoxicity compared to untreated controls

Potency $\mathrm{ED}_{50 \mathrm{p}} / \mathrm{ED}_{50 \mathrm{CNT}}$ - Relative deposited dose causing $50 \%$ of cytotoxicity among pristine incinerated thermoplastic $\left(E_{50 \mathrm{p}}\right)$ compared to CNT-containing analog $\left(E_{50 C N T}\right)$ at the same time point. Potency comparisons across time points were not made

N.D. Potency $\mathrm{ED}_{50 \mathrm{p}} / \mathrm{ED}_{50 \mathrm{CNT}}$ value could not be determined as $\mathrm{ED}_{50}$ value for one or both groups exceeded highest concentration tested. None of the filtered preparations caused significant cytotoxicity in PSAECs in PI- observed in acute cytotoxicity assessment. Further, we examined proliferative behaviour of Beas-2B after treatmments in order to correlate particle-mediated effects to $\mathrm{B}[\mathrm{a}] \mathrm{P}$, the archetypal PAH.

Having affirmed dose-dependent CYP1 activity induction, indicating AhR mobilization, follow-up highcontent screening showed perturbations in cell cycle phase distribution and nuclear morphometry due to $\mathrm{B}[\mathrm{a}] \mathrm{P}$ and the high dose of $\mathrm{PC}-\mathrm{CNT}$ in asynchronous Beas-2B cells (Fig. 6). The $1.2 \mu \mathrm{g} / \mathrm{cm}^{2}$ dose PC-CNT caused a substantial reduction of mitotically active cells (phospho-Histone $\mathrm{H}_{3}{ }^{\mathrm{Ser} 10}+$ ), nuclear enlargement, and enhancement of G2- and S-phase prevalence (Fig. 6a-b). Despite enhancement of $\mathrm{S}$-phase prevalence, EdU uptake, a proxy of DNA synthesis, was reduced. Accompanying cell cycle and morphological parameters, PCCNT caused a significant increase in ROS (Fig. 6c) as well as $\gamma \mathrm{H} 2 \mathrm{AX}$ formation (Fig. 6d), the latter a marker of genotoxic double strand breaks $[56,57]$. Perturbations of cell cycle kinetics were transient, as assessment of doubling time after subacute treatment suggested that neither PC nor PC-CNT reduced proliferative capacity between $0.06 \mu \mathrm{g} / \mathrm{cm}^{2}$ and $0.2 \mu \mathrm{g} / \mathrm{cm}^{2}$ (Fig. 6e), despite almost complete abrogation of clonogenic growth when exposed to $>0.6 \mu \mathrm{g} / \mathrm{cm}^{2} \mathrm{PC} /-\mathrm{CNT}$ (Fig. 6f). Among $\mathrm{B}[\mathrm{a}] \mathrm{P}$-only treated Beas-2B cells, phosphorylation of Chk1 and cdc2 was reversible upon pre-treatment with $10 \mu \mathrm{M}$ of the CYP1 inhibitor $\alpha \mathrm{NF}$ (Fig. 6g), though PC/ PC-CNT-treated Beas-2B cells did not exhibit inhibition of cell cycle kinetics as detected by proteomic analysis (Fig. 6h). A summary of endpoints for the test particlestreated Beas-2B cells are presented in Table 5. In pSAEC model, all test particles did not cause significant increases in intracellular ROS as reported by CellROX green, denoting treatments did not affect intracellular redox potential (Fig. S5). Additionally, neither PC/PC-CNT nor B[a]P induced significant $\gamma \mathrm{H} 2 \mathrm{AX}$ formation in pSAECs, while no conclusions could be drawn on PU/PU-CNT-treated cells since thermoplastic-associated non-specific fluorescence caused substantial false-positivity (Fig. S6).

\section{Discussion}

The results demonstrate aerosolized particulate matter from incinerated polycarbonate causes significant cytotoxicity and 


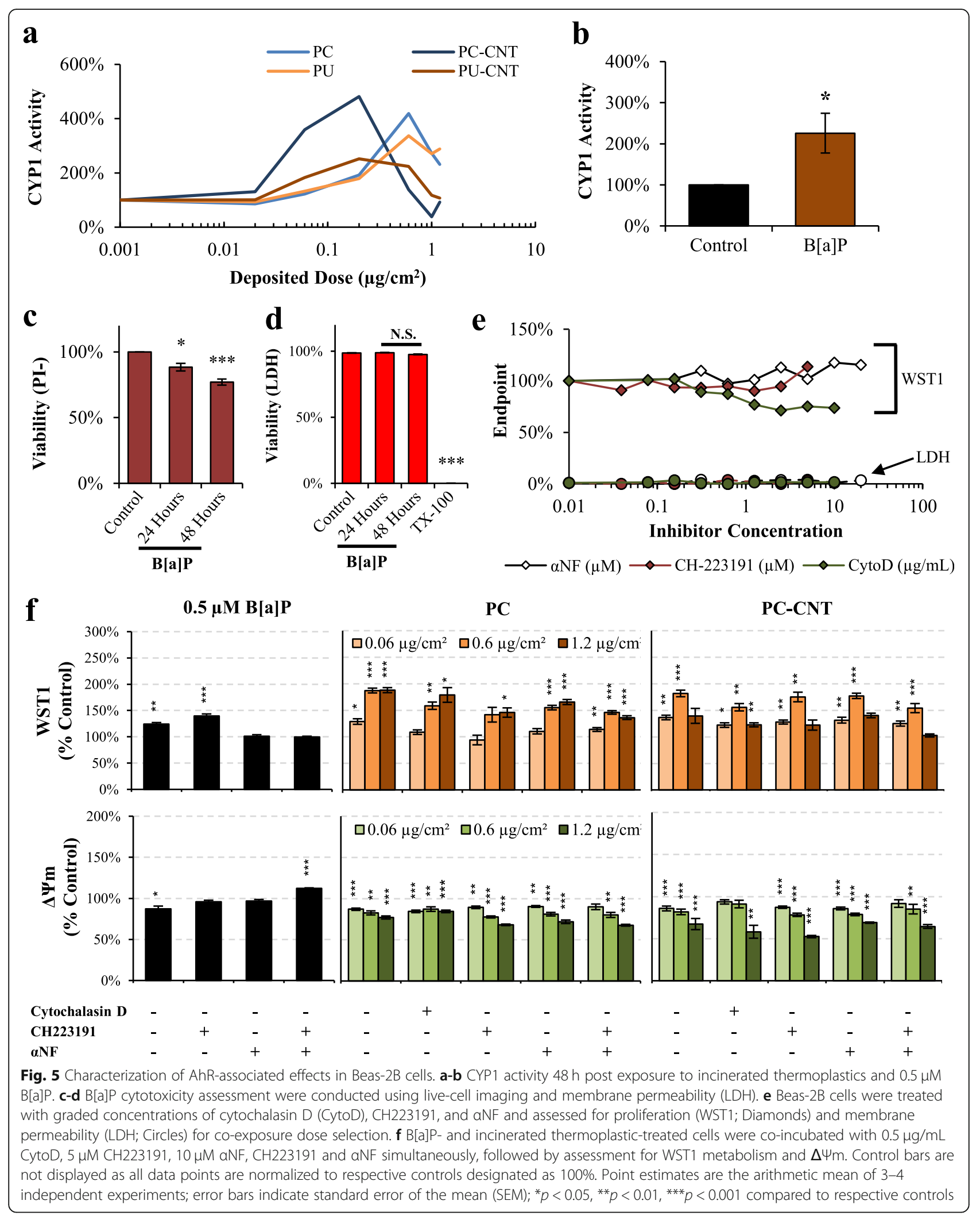




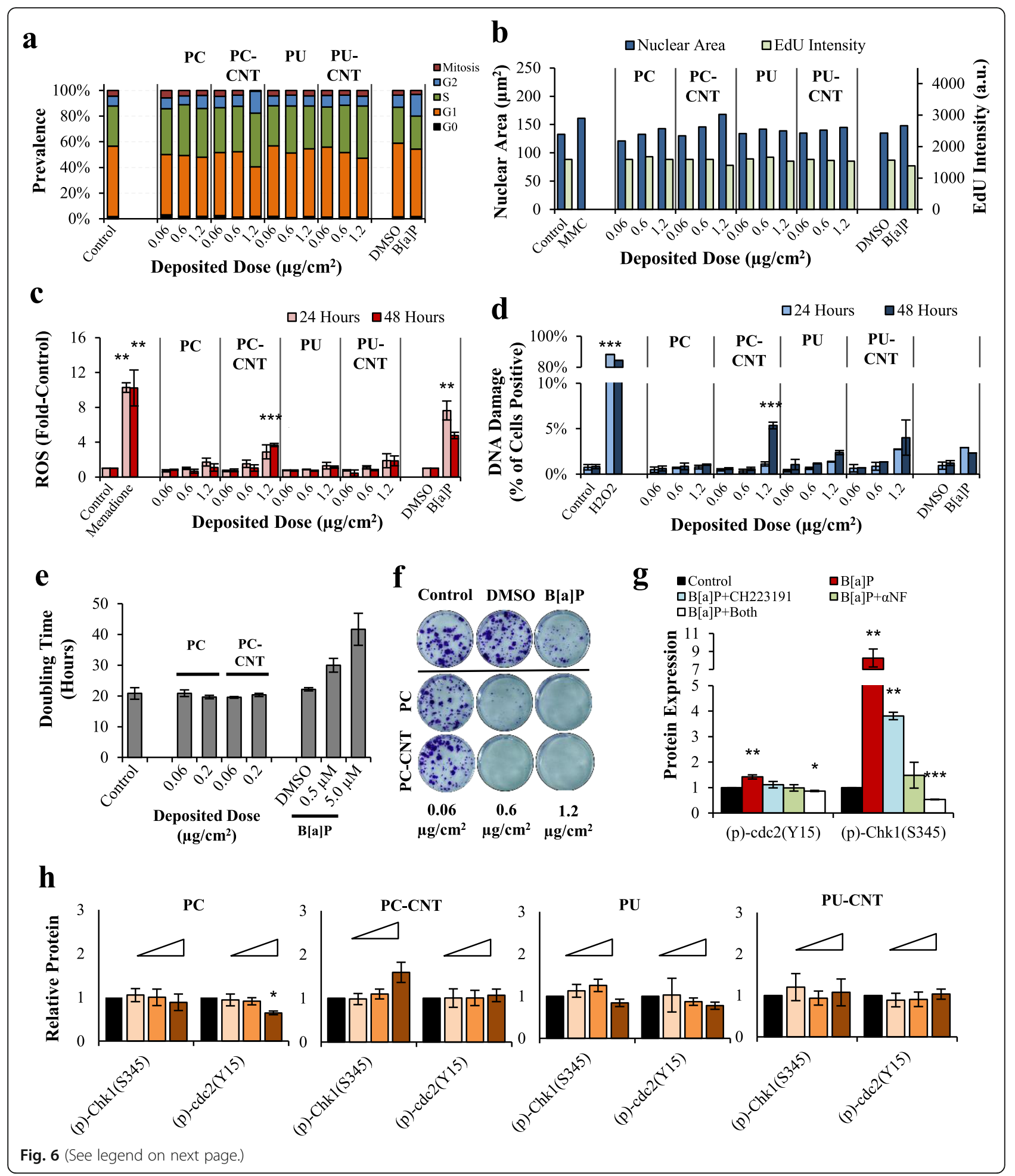


(See figure on previous page.)

Fig. 6 Cell cycle analysis and nuclear morphometry in Beas-2B cells. a-b Quantitative binning of cell cycle-specific phases and nuclear morphometry, including nuclear area and EdU uptake [in arbitrary units (a.u.)] analyzed from high-content screening 24-h post treatment. MMC = $0.76 \mathrm{ng} / \mathrm{mL}$ mitomycin C - a clastogen control. Results are from a single experiment. c Intracellular ROS was measured 24 and $48 \mathrm{~h}$ after treatment; $100 \mu \mathrm{M}$ Menadione served as a positive control for ROS generation. B[a]P-induced intracellular ROS was significant at both time points - limited space precluded asterisk placement above the 48-h time point. $\mathbf{d}$ Cells treated for 24 and $48 \mathrm{~h}$ were stained for $y \mathrm{H}_{2} \mathrm{AX} ; \mathrm{H}_{2} \mathrm{O}_{2}$ served as a positive control. Results are presented as percent of cells positive for yH2AX out of the total cell population (> 1000/experiment). e Cells treated with PC/-CNT and B[a]P assessed for doubling time from growth curves from 3 independent experiments. $\mathbf{f}$ Clonogenic assay of Beas-2B cells treated for 3 days. $\mathbf{g}$ Western Blot analysis of B[a]P-treated cells for $24 \mathrm{~h}$ with and without inhibitors for AhR (Ch223191) or CYP1 (aNF). $\mathbf{h}$ Western Blot analysis of Beas-2B treated with $0.06,0.6$, and $1.2 \mu \mathrm{g} / \mathrm{cm}^{2}$ cells for $24 \mathrm{~h}$; controls are solid black whilst concentrations are indicated by wedge where the $1.2 \mathrm{\mu g} / \mathrm{cm}^{2}$ treatment is represented by the thickest portion of the wedge. Point estimates for $\mathbf{d}$ and $\mathbf{f}$ are the arithmetic mean of $2-3$ independent experiments; error bars indicate standard error of the mean (SEM); ${ }^{*} p<0.05,{ }^{* *} p<0.01,{ }^{* * *} p<0.001$ compared to respective controls

alterations in metabolic function dose-dependently in bronchial epithelial cells, but not in small airway epithelial cells. Addition of $3 \% \mathrm{CNT}$ in the polycarbonate matrix significantly enhanced measured endpoints in bronchial epithelial cells. Conversely, aerosolized particulate matter of pristine and $0.1 \% \mathrm{w} / \mathrm{w}$ CNT-enabled polyurethane were not cytotoxic in both in vitro models.

Deposition of virgin and iNEC particles tested was confirmed using enhanced darkfield and electron microscopy, demonstrating not only deposition, but also endocytosis of all particles examined. Despite little apparent cytotoxicity or genotoxicity, PU/PU-CNT tended to accumulate more extensively in both cell types than PC analogues; the reasoning of which was not investigated in this work. Baulig et al. [58] noted a similar phenomenon when examining airborne particulate matter, DEP, and carbon black in a human bronchial epithelial model, thus attributing partially the underlying toxicodynamic effects to particle-specific physiochemical parameters independent from access to the intracellular space. Whether endocytosis represents a unified fate for combusted carbonaceous materials or the product of an in vitro particle-medium interaction, e.g., proteinaceous corona that facilitates endocytosis, has yet to be elucidated [59-61]. Since cytochalasin D co-treatment with $\mathrm{PC} / \mathrm{PC}-\mathrm{CNT}$ did not completely mitigate $\Delta \Psi_{\mathrm{m}}$ reductions, the contribution of partico-extracellular interactions as well as cytochalasin D-insensitive uptake, or a combination of uptake pathways [62], remains unknown in the current system. Thorugh filtration studies, the presence of particles, particularly $\mathrm{PC} / \mathrm{PC}-\mathrm{CNT}$, were essential for eliciting the cytotoxicity and metabolic dispruption observed in bronchial cells.

As determined thorugh filtration studies and the use of $\mathrm{B}[\mathrm{a}] \mathrm{P}$ as a $\mathrm{PAH}$ control, the incinerated parent matrix largely determined cytotoxicity and metabolic disruption, while the incorporation of CNT exacerbated observable parent matrix effects. We do not expect direct contributory toxicity from intact CNTs as they have been shown to thermally decompose to $\mathrm{CO}_{2}$ at $800{ }^{\circ} \mathrm{C}$ [63-65], even when incorporated in thermoplastic matrices [42]. While contribution to toxicodynamic effects of CNT-associated impurities, such as iron and aluminum, cannot be discounted [66], this was not explored further in this investigation. For both metals, high doses, typically exceeding the particular doses utilized in this study, are required to induce cytotoxic endpoints $[67,68]$. Byproducts of incineration, such as PAHs, provide a likely source of accounting for the enhanced cytotoxicity profile, particularly since incineration of iNECs utilized in this study significantly enhance the PAH profile of the aerosol particulates [29]. Despite enhancement in PAH generation associated with these particles, we did not observe $\mathrm{PAH}$-isolated effects in either Beas-2B or pSAECs. Among Beas-2B cells, filtration studies resulted in only mild metabolic changes with no cytotoxicity, denoting PAH leaching into the medium did not contribute substantially to the observed effects in Beas-2B cells.

Table 5 Summary of Measured Endpoints - Beas-2B

\begin{tabular}{|c|c|c|c|c|c|c|c|c|c|c|c|}
\hline \multirow[b]{2}{*}{ Agent } & \multicolumn{4}{|c|}{ Cytotoxicity } & \multicolumn{5}{|c|}{ Genotoxicity } & \multicolumn{2}{|c|}{ Mechanistic } \\
\hline & $\Delta \psi \mathrm{m}$ & LDH Release & WST1 & Clonogenic Proliferation & $y H 2 A X$ & (p)-Histone $\mathrm{H} 3$ & Nuclear Area & $\begin{array}{l}\text { EdU } \\
\text { Uptake }\end{array}$ & Cell Cycle Checkpoint & ROS & CYP1 \\
\hline PC & $\downarrow$ & $\uparrow$ & $\uparrow \downarrow^{*}$ & $\downarrow$ & - & - & - & - & - & - & $\uparrow$ \\
\hline PC-CNT & $\downarrow$ & $\uparrow$ & $\uparrow \downarrow^{*}$ & $\downarrow$ & $\uparrow$ & $\downarrow$ & $\uparrow$ & $\downarrow$ & - & $\uparrow$ & $\uparrow$ \\
\hline PU & - & - & $\uparrow$ & N.D. & - & - & - & - & - & - & $\uparrow$ \\
\hline PU-CNT & - & - & $\uparrow$ & N.D. & - & - & - & - & - & - & $\uparrow$ \\
\hline $\mathrm{B}[\mathrm{a}] \mathrm{P}$ & $\downarrow$ & - & $\uparrow$ & $\downarrow$ & - & - & $\uparrow$ & $\downarrow$ & + & $\uparrow$ & $\uparrow$ \\
\hline
\end{tabular}

$\downarrow$ Significant reduction at any tested dose; $\uparrow$ Significant increase at any tested dose. - No change at any dose. N.D. Not Determined. *Low depositional dose caused increased metabolism but reduced at higher concentrations 
To ascertain bioavailability of PAHs adsorbed to the particles, we co-treated PC/PC-CNT with $\alpha \mathrm{NF}$ and/or $\mathrm{CH} 223191$. Despite reversal of the significant $\Delta \Psi_{\mathrm{m}}$ depolarization and WST1 metabolic changes among $\mathrm{B}[\mathrm{a}] \mathrm{P}$-treated Beas-2B cells, both inhibitors were iineffective in reversing effects observed among PC/PC-CNT treatment groups, denoting the particles as the primary source of cytotoxic injury and metabolic changes.

Similar to cytotoxic endpoints, the primary particle of the incinerated thermoplastics was the primary contributor to genotoxicity and changes in cell cycle kinetics in Beas-2B cells. Neither PC/PC-CNT nor B[a]P induced $\gamma \mathrm{H} 2 \mathrm{AX}$ formation in pSAECs at the tested doses in this investigation. PU/PU-CNT were found to have interfered with assessment, leading to erroneous positivity dose-dependently, the source of which was not examined in the current investigation. The high-dose PCCNT resulted in significant increases in $\gamma \mathrm{H} 2 \mathrm{AX}+$ and decreases in phospho-Histone $\mathrm{H} 3{ }^{\mathrm{Ser} 10}+$ nuclei in Beas2B cells. Similarly, nuclear enlargement was in similar magnitude as mitomycin c - an archetypal clastogen [69]. Taken together, the combination of increased $\gamma \mathrm{H} 2 \mathrm{AX}$ formation and reduced phospho-Histone $\mathrm{H} 3{ }^{\mathrm{Ser} 10}$ + have been shown as predictive multi-parameter phenotypes for classifying agents as clastogenic genotoxicants [70, 71]. In comparison, $\mathrm{B}[\mathrm{a}] \mathrm{P}$, a known clastogen $[52,54,55,72]$, caused insignificant elevations with positive $\gamma \mathrm{H} 2 \mathrm{AX}$ nuclear localization in percent of cells as well as stark changes in nuclear area and EdU incorporation. The lack of significant genotoxicity, as measured by $\gamma \mathrm{H} 2 \mathrm{AX}$ localization, at the tested dose of $0.5 \mu \mathrm{M}$ $\mathrm{B}[\mathrm{a}] \mathrm{P}$ was consistent with other reports [73, 74]. B[a]P caused modest increases in G2-phase and slight reductions in S-phase and mitotically active cells, largely in accordance with previous findings in the Beas-2B cell line $[45,75,76]$. These three studies relied on cell cycle determination using Gaussian-derived parameterization of DNA content from flow cytometric analyses that are sensitive to misclassification of early- and late-phase $S$ cells to G0/G1 and G2/M, respectively [77], as well as the inability to discriminate $\mathrm{G} 2$ versus mitosis, unless specific staining methods are employed [78]. As such, the method employed to characterize cell cycle kinetics allows for a more complete cell cycle distribution than nuclei intensity-based methods.

Kinetic changes in cell cycle among B[a]P-treated cells were attributable to phosphorylation of Chk-1(S345) and cdc2(Y15) associated with cell cycle checkpoint activation [79-85], and were reversible upon pre-treatment with the CYP1 inhibitor $\alpha$ NF. These results indicate intact CYP1 metabolism as implicated in precipitating alterations in cell proliferation in accordance previous findings [86]. Conversely, PC/PC-CNT did not significantly alter phosphorylation of Chk-1(S345) and cdc2(Y15) or doubling time, despite being acutely cytotoxic at concentrations $>1.0 \mu \mathrm{g} / \mathrm{cm}^{2}$. The overall cytological effects of $\mathrm{PC} /$ PC-CNT occurred independently of PAH-associated effects in our model system, despite CYP1 activity induction. The intracellular concentration of bioavailable PAHs likely remained below the threshold required for inducing genotoxic insult among thermoplastic-treated Beas-2B cells, though this is difficult to ascertain given the heterogeneous PAH mixture of these samples and unmeasured quantity of particle-associated PAHs in the present system. However, a limitation of this study pertains to the nature of particle preparation; namely, aerosolized particles were collected and extracted from filters into an aqueous suspension for in vitro testing in a submerged system. Therefore, any contribution to PAH bioavailability by lung lining fluid [87] remains unknown as desorption in these fluids may enhance $\mathrm{B}[\mathrm{a}] \mathrm{P}$ bioavailability [88], and subsequently produce a PAH-mediated effect in vivo that we were unable to recapitulate. Overall, the same incinerated thermoplastics treated pSAECs showed a blunted cytotoxic response compared to the magnitude of that observed in Beas-2B, demonstrating cell-specific heterogeneity in sensitivity to incinerated thermoplastics to cytotoxicity. Likewise, metabolic heterogeneity between the pSAECs and Beas-2B was observed. CYP1 metabolism in pSAECs was observed for most iNECs, except by PC-CNT, while $0.5 \mu \mathrm{M}$ B[a]P did not induce CYP1 activity. To address $\mathrm{B}[\mathrm{a}] \mathrm{P}$, Chang et al. [89] has shown pSAECs demonstrate a blunted response to AhR ligands compared to Club cells, resulting in modest transcriptional upregulation of CYP1 isoforms upon treatment with $\mathrm{B}[\mathrm{a}] \mathrm{P}$. Therefore, pSAECs are likely inherently less sensitive to PAH-induced CYP1 transcription and subsequent metabolism compared to bronchial cells; the results from the current investigation tend to support this notion on the one hand. On the other hand, iNECs induced robust CYP1 activity in pSAECs whose activity maxima were lower than Beas-2B cells, suggesting either the PAH threshold to induce metabolic induction in pSAECs was exceeded by iNECs or iNECs may cause metabolic induction independently of $\mathrm{PAH}$-associated nuclear receptors, such as AhR.

Due to the substantial induction of WST1 metabolism by PC/PC-CNT, we employed several methods to delineate changes in metabolism, membrane permability, proliferation, and mitochondrial function to qualify the in vitro response observed. The discrepancy between WST1 and PI-/LDH was attributable to the hyperstimulatory WST1 metabolism observed along the range of doses examined, whereas these treatment groups did not demonstrate enhanced proliferative capacity (See Cell Cycle and Genotoxicity Section). As such, the dose at which WST1 metabolism inflection occurs is above $1.0 \mu \mathrm{g} / \mathrm{cm}^{2}$, delineating the dose at which cytotoxicity outweighed hyperstimulatory metabolism. Since PI- method 
integrates both cell number as well as membrane permability, this method serves as an indicator of proliferative capacity and membrane permeability. WST1, by contrast, measures the rate of formazan metaboplism via reduction of an electron-coupling intermediary [90]. Recently, B[a]P has been shown to upregulate genes associated with the pentose phosphate pathway [91], leading to enhanced NADPH formation and WST1 metabolism [92]. While the prevailing interpretation of formazan metabolism centers around mitochondrial function, the authors counter such an interpretation under the circumstances of the current manuscript, especially since we observed significant reductions in $\Delta \Psi_{\mathrm{m}}$ among Beas-2B cells treated with both $\mathrm{B}[\mathrm{a}] \mathrm{P}$ and PC/PC-CNT. B[a]P and depositional doses $>0.2 \mu \mathrm{g} / \mathrm{cm}^{2}$ $\mathrm{PC} / \mathrm{PC}-\mathrm{CNT}$ likely resulted in enhanced NADPH formation in Beas-2B cells without overt cytotoxicity, leading to hyperstimulatory WST1 metabolism. Given the results of cell cycle analysis, enhanced WST1 could not be attributed to enhanced proliferation. PI- showed no discernible changes up to $0.6 \mu \mathrm{g} / \mathrm{cm}^{2}$ which was observed as the point of departure for PC-CNT for cytotoxicity. Therefore, interpretation relied on PI- as the primary representation of cytotoxicity, while WST1 likely served as a proxy of $\mathrm{NADPH}$-associated metabolic induction.

The cytotoxicity potency differences of PC vs. PCCNT would not be readily identifiable when regressing solely on administered dose. In effect, the results suggest, without ascribing dosing metrics based on differential deposition of each thermoplastic, characterization by administration dose underestimates the cytotoxic potency of both PC and PC-CNT. Further, interpretation of administrative doses does not capture the obvious potency differences between the two incinerated materials, thus, underscoring the importance of characterizing delivered dose in order to accurately realize comparative cytotoxic potency [93].

\section{Conclusions}

In conclusion, all virgin and CNT-containing thermoplastics tested were to some extent endocytosed by the in vitro models of the human bronchus (Beas-2B) and the distal airway (pSAECs). In both cell lines, PU/PUCNT proved highly endocytosed but not acutely cytotoxic. By contrast, PC/PC-CNT was acutely cytotoxic in both cell lines, while Beas-2B cells uniquely more sensitive than pSAECs. In Beas-2B cells, PC-CNT approximately 2-fold more cytotoxic than PC. Presuming the dose group of $\mathrm{B}[\mathrm{a}] \mathrm{P}$ utilized in this investigation serves as a surrogate for total PAHs, adsorbed PAHs contributed negligibly to the overall toxicodynamic effect acutely, at least among Beas-2B cells. Observation of PC and PC-CNT induced increased WST1 metabolism, and DNA damage in Beas-2B cells need further sub-chronic investigation to ascertain if exposure to these incinerated thermoplastics may pose a potential carcinogenic or asthmatic risk to human health, particularly in the upper airway.

\section{Methods}

Methods described here have been abridged. For the complete details on the methods utilized in this investigation, please refer to the Additional fsile 2.

\section{Particle characterization and dosimetry}

All incinerated virgin and NECs used in this study were provided by Dr. P. Demokritou's lab at Harvard University following extraction from in-line filters. Generation of incinerated thermoplastic samples using the Harvard INEX system and particle extraction are described elsewhere [94-96]. Previous work using these materials fully characterized their physicochemical properties, including CNT loading and signature impurities $[29,42]$.

Particle deposition for thermoplastics was modeled using the Harvard Distorted Grid (DG) model as described in GM DeLoid, JM Cohen, G Pyrgiotakis and P Demokritou [97] to estimate average deposited dose up to $72 \mathrm{~h}$ post-treatment. Deposited modeling was conducted using MatLab v. R2017b (MathWorks, Inc., Natick, MA). Except for data derived from dynamic light scattering and deposited modeling, methodological approaches for ascertaining medium density, viscosity, and refractive index may be found within Table S1 and Supplemental Methods.

\section{Hydrodynamic diameter by dynamic light scattering}

The critical delivered sonication energy $\left(\mathrm{DSE}_{\mathrm{cr}}\right)$, which is the energy necessary to disperse $1 \mathrm{mg} / \mathrm{mL}$ of the particle suspension in $\mathrm{dH}_{2} \mathrm{O}$ was derived previously as $1066 \mathrm{~J} /$ $\mathrm{mL}$ for all thermoplastics [41]. Stock particle suspensions in $\mathrm{dH}_{2} \mathrm{O}$ were sonicated using a Cup Horn Sonicator (Sonics VibraCell VCX-750 with Cup-type Sonicator; Newton, CT) immediately prior to dilution to $0.1 \mathrm{mg} /$ $\mathrm{mL}$ in $\mathrm{dH}_{2} \mathrm{O}$ or culture medium. A Zetasizer Nano ZS and DipCell for electrophoretic measurements (Malvern Instruments; Malvern, United Kingdom) was used to evaluate hydrodynamic diameter, zeta potential, and conductivity of particle suspensions. Suspension $\mathrm{pH}$ was measured with a standard $\mathrm{pH}$ meter (Accumet Model 50, Fisher Scientific). Dispersant parameters required for DLS measurements are included in Table S1.

\section{Effective density}

To assess effective density via the volumetric centrifugation method [97] using packed cell volume tubes (Techno Plastic Products, A.G., Trasadigen, Switzerland) and pellet volume measured manually using a PCV tube ruler (Techno Plastic Products, A.G.). The density of the parent material, packed pellet volume, and medium 
density were performed in triplicate and used to calculate the effective density $\left(\rho_{E V}\right)$ requisite for modeling.

\section{Endotoxin content}

All thermoplastics were screened for endotoxin content at a suspension concentration of $10 \mu \mathrm{g} / \mathrm{mL}$ in endotoxinfree water according to the NCL Method STE-1.1 [98], and were found to be below the detection limit of $<0.01$ $\mathrm{EU} / \mathrm{mL}$ via the LAL chromogenic method (Pierce Biotechnology, Inc.; Rockford, IL). In assessing endotoxin adsorption, $10 \mu \mathrm{g} / \mathrm{mL}$ particle suspensions were spiked with $0.05 \mathrm{EU} / \mathrm{mL}$, which resulted in bound endotoxin ranging from 0 to $23 \%$ (Fig. S7), depending on the thermoplastic. The spike-in control of $0.05 \mathrm{EU} / \mathrm{mL}$ was chosen as it was the midpoint between the minimum and maximum concentrations of the high-sensitivity method utilized $(0.01-0.1 \mathrm{EU} / \mathrm{mL})$, allowing for estimation within the method's dynamic range.

\section{Cell culture and treatment}

Human bronchial epithelial (Beas-2B) cells were purchased from ATCC (CRL-9609, Manassas, VA), and cultured in complete airway epithelial growth medium (AEGM) purchased from PromoCell, GmbH (Heidelberg, Germany) supplemented with $10 \mathrm{ng} / \mathrm{mL}$ epidermal growth factor, $5 \mu \mathrm{g} / \mathrm{mL}$ insulin, $0.5 \mu \mathrm{g} / \mathrm{mL}$ hydrocortisone, $0.5 \mu \mathrm{g} /$ $\mathrm{mL}$ epinephrine, $10 \mu \mathrm{g} / \mathrm{mL}$ transferrin, $0.1 \mathrm{ng} / \mathrm{mL}$ retinoic acid, $6.7 \mathrm{ng} / \mathrm{mL}$ triiodo-L-thyronine, and $4 \mu \mathrm{L} / \mathrm{mL}$ Bovine pituitary extract. Experimentation on Beas-2B cells was performed on cells passaged between a total of 7 and 14 times. Human primary small airway epithelial cells (pSAECs) were purchased from PromoCell and maintained in small airway epithelial growth medium (SAGM) supplemented with $10 \mathrm{ng} / \mathrm{mL}$ epidermal growth factor, $5 \mu \mathrm{g} / \mathrm{mL}$ insulin, $0.5 \mu \mathrm{g} / \mathrm{mL}$ hydrocortisone, $0.5 \mu \mathrm{g} / \mathrm{mL}$ epinephrine, $10 \mu \mathrm{g} / \mathrm{mL}$ transferrin, $0.1 \mathrm{ng} / \mathrm{mL}$ retinoic acid, $6.7 \mathrm{ng} / \mathrm{mL}$ triiodo-L-thyronine, $4 \mu \mathrm{L} / \mathrm{mL}$ Bovine pituitary extract, and $2.5 \mathrm{mg} / \mathrm{mL}$ fatty acid-free Bovine serum albumin from the same vendor. Experimentation on pSAECs was performed on cells passaged between 4 and 8 times. Cultures were maintained in a humidified $37^{\circ} \mathrm{C}$ incubator (Fisher Scientific) under an atmosphere of $5 \% \mathrm{v} / \mathrm{v} \mathrm{CO}$ and balance air.

Both cell types were seeded into microplates at subconfluency as described for individual assays below. The culture medium was aspirated and replaced with fresh pre-warmed medium containing treatment particle at designated delivered doses, calculated as described above. $1.0 \mathrm{mg} / \mathrm{mL}$ stock solutions of all test particles were sonicated to immediately before serial dilution in growth medium. All dosing designations are reported as deposited dose $\left(\mu \mathrm{g} / \mathrm{cm}^{2}\right)$. For indicated experiments, cells were pre-incubated with an actin polymerization inhibitor cytochalasin D (CytoD; Millipore-Sigma), aryl hydrocarbon receptor inhibitor CH223191 (MilliporeSigma), or an aryl hydrocarbon receptor/CYP1 inhibitor alpha-naphthoflavone ( $\alpha$ NF; Millipore-Sigma), for 1 hour before the incinerated thermoplastic treatments, and continued for the duration of incinerated thermoplastic exposure.

\section{Microscopy}

To evaluate particle uptake in SAECs and Beas-2B cells, two methods of microscopic analysis were employed.

\section{Enhanced Darkfield microscopy}

Cells were seeded onto round laser-cut glass coverslips (Schott, A.G.; Jena, Germany) within 6-well tissue culture-treated microplates at a density of 150,000 cells per well. Two days later, cells were treated with $0.6 \mu \mathrm{g} /$ $\mathrm{cm}^{2}$ of each thermoplastic in complete medium for $48 \mathrm{~h}$, fixed in $4 \%$ formaldehyde in DPBS, and mounted on slides. Coverslips were then imaged at $60 \mathrm{X}$ using the CytoViva EDM system (CytoViva, Inc.; Auburn, AL).

\section{Electron microscopy}

Cells were seeded at a density of 150,000 cells per well in tissue culture-treated 6-well microplates. Cells were then treated for $48 \mathrm{~h}$ with $1.2 \mu \mathrm{g} / \mathrm{cm}^{2}$ incinerated thermoplastics, trypsinized with $0.25 \%$ Trypsin EDTA, washed twice with D-PBS, and fixed in Karnovsky's fixative overnight as a cell suspension. Cells were pelleted, embedded in agarose, fixed, stained, and embedded in epon prior to sectioning. Particle preparations were imaged for SEM using the Hitachi S4800 field-emission scanning electron microscope (FESEM; Tokyo, Japan) with energy dispersive $\mathrm{x}$-ray (EDX) generated qualitative elemental analysis (Bruker Nano, Berlin, Germany). Cell and particle preparations for TEM were imaged using the JEOL 1400 transmission electron microscope (Tokyo, Japan).

\section{Cytotoxicity, membrane permeability, and proliferation assessment}

Five measures were employed to describe cytotoxicity, membrane permeability, and proliferative capacity: WST1, LDH, clonogenic assay, live cell imaging, and mitochondrial membrane potential. Except for the clonogenic assay, Beas-2B and pSAECs were plated at a density of 5000 and 2500 cells per well, respectively, in 96-well microplates 2 days prior to exposure. For the post-treatment proliferative capacity, cells were plated in 6-well microplates at a density of 50,000 cells per well 2 days prior to treatment. Benzo[a]pyrene $(\mathrm{B}[\mathrm{a}] \mathrm{P} ; 0.5 \mu \mathrm{M})$ served as a PAH control and was purchased from Millipore-Sigma. All colorimetric endpoints were acquired using the SpectraMAX Plus 384 (Molecular Devices; San Jose, California) and SoftMax Pro v. 5.4.1 data acquisition software. 


\section{WST1 tetrazolium reduction}

Cells were treated with indicated particle in growth medium for 24-48 h prior to assessment with WST1 (Millipore-Sigma, St. Louis, MO). After incinerated thermoplastic exposure an aliquot of supernatant abstracted into a clean clear-bottom microplate for LDH assessment (see below). The remaining culture medium was replaced with fresh medium, and the WST1 assay was performed according to the manufacturer's instruction with a 2-h incubation period. WST1 formazan was quantitated at $450 \mathrm{~nm}$ with a reference wavelength of 650 $\mathrm{nm}$. Treatment groups were normalized against mediumonly controls, which were arbitrarily denoted as $100 \%$.

\section{Lactate dehydrogenase activity}

The LDH assay was performed according to manufacturer's instructions (F. Hoffmann-La Roche AG; Basel, Switzerland), with a color development incubation of 25 min at room temperature. Results are presented as a percentage of the dynamic range enclosed by the spontaneous $\mathrm{LDH}$ release designated as $100 \%$ and total $\mathrm{LDH}$ release (Triton X-100-treated controls ( $1 \% \mathrm{v} / \mathrm{v}$ for $2 \mathrm{~h})$ ) as $0 \%$. Particle-only dose-dependent LDH activity interference is presented in Fig. S8; adjustment was performed as described in the Supplemental methods.

\section{Post-treatment proliferative capacity}

Beas-2B cells were plated in 6-well plates at a density of 50,000 cells per well. After 2 days, cells were treated with thermoplastics or $\mathrm{B}[\mathrm{a}] \mathrm{P}$ for 3 days, the cells washed once with DPBS, and then retreated for an additional 2 days prior to trypsinization and replating in 96-well microplates at a density of 1000 cells/well to quantitate doubling time using WST1. WST1 optical density values were used to derive the doubling time in log-phase growth using the package "growthcurves" in the statistical program R version 3.6 (R Project for Statistical Programming; Vienna, Austria).

\section{Clonogenic assay}

Beas-2B cells were plated in 6 well plates at an initial density of 300 cells per well [99]. The medium was refreshed with incinerated thermoplastic-containing AEGM, and $0.5 \mu \mathrm{M} \mathrm{B}[\mathrm{a}] \mathrm{P}$ or DMSO vehicle as control treatments. The cells were gently washed once with growth medium on day three and held in growth medium for an additional 7-10 days, or until individual colonies were apparent. Cells were then fixed with $4 \%$ paraformaldehyde for $15 \mathrm{~min}$, and stained with $0.5 \% \mathrm{w} / \mathrm{v}$ crystal violet, followed by destaining in $\mathrm{dH}_{2} \mathrm{O}$ and imaging.

\section{Live cell imaging}

Propidium iodide (PI) is known to be excluded from membrane-intact cells and was used in combination with raw cell counts as a proxy for cellular cytotoxicity. After a 24- or 48-h exposure, thermoplastic-containing medium was replaced with fresh AEGM supplemented with $1 \mu \mathrm{M}$ Hoechst 33342 (Thermo Fisher) and $5 \mu \mathrm{g} / \mathrm{mL}$ PI (Thermo Fisher), and imaged using the ImageXpress Micro XLS with MetaXpress software v.6 (Molecular Devices). Nuclei were visualized using a standard DAPI filter set, while necrotic cells were visualized using a standard Cy5 filter set. Hoechst 33342-reported cell number for each treatment group was normalized against untreated controls, and the remaining population was dichotomously assigned viable (PI negative) or necrotic (PI positive) based on Triton X-100-treated cells as intensity-based gating controls for PI positivity scoring. The integrated viability estimate adjusted for cell number (PI-) captures lytic cytotoxicity as well as reduction in proliferation. Results are expressed as percent PI- viable cells.

\section{Mitochondrial membrane potential $\left(\Delta \psi_{m}\right)$}

$\Delta \Psi \mathrm{m}$ was assessed ratiometrically using JC-1 $\left(5,5^{\prime}, 6,6^{\prime}\right.$ tetrachloro-1,1',3,3' -tetraethyl-benzimidazolylcarbocyanine iodide) dye. Beas-2B or pSAECs were plated in clear-bottom, black-walled 96-well microplates and treated with incinerated thermoplastics as described above. After 24-h treatments, growth medium was replaced with fresh medium containing $1 \mu \mathrm{g} / \mathrm{mL}$ of JC-1 (ThermoFisher Scientific) and $1 \mu \mathrm{M}$ Hoechst 33342 for $15 \mathrm{~min}$. Cells were washed twice with fresh, pre-warmed growth media prior to assessment. Ten micrometre valinomycin for $30 \mathrm{~min}$ immediately after $\mathrm{JC}-1$ staining served as a $\Delta \Psi \mathrm{m}$ dissipation control. J-aggregates and monomers of JC-1 were quantitated at excitation/emission wavelength sets of $535 / 590 \mathrm{~nm}$ and $485 / 530 \mathrm{~nm}$, respectively, using the SpectraMax M4 multimodal plate reader (Molecular Devices). Data were acquired using the SoftMax Pro v. 6.2.1 data reduction software (Molecular Devices). Using the ImageXpress high-content imager nuclei were visualized using a standard DAPI filter set, while J-aggregates and monomers were visualized using TRITC and FITC filters, respectively. An identification mask was generated based on nuclear Hoechst 33342 intensity and overlaid onto each nucleus for single cell identification. Similar masks were applied to TRITC and FITC channels based on dye intensity using the MetaXpress v.6 Software (Molecular Devices) prior to single-cell analysis in R. Similar to analysis using the microplate reader, $\Delta \Psi \mathrm{m}$ was determined using average cell TRITC-to-FITC ratios.

\section{Proliferation and nuclear morphometry}

5-Ethynyl-2'-deoxyuridine (EdU) incorporation in actively proliferating cells [100] was performed using the Click-It EdU 647 Imaging Kit according to 
manufacturer's instructions (ThermoFisher Scientific). Briefly, Beas-2B cells plated at 2500 cells per well in 96 well plates 2 days prior to exposure. Cells were then treated with incinerated thermoplastics for $24 \mathrm{~h}$ prior to incubation with $10 \mu \mathrm{M}$ of EdU reagent in fresh complete culture medium for $60 \mathrm{~min}$. Incorporated EdU was detected with an Alexa 647-conjugated azide as per manufacturer's instructions (Thermo-Fisher), followed by probing with phospho-Histone H3 (1:400) and Ki-67 (1:400) in 1\% BSA in D-PBS for $1 \mathrm{~h}$. Phospho-Histone H3 and Ki-67 were then labeled with Alexa-555- and Alexa488-conjugated $\left.\mathrm{F}(\mathrm{ab})_{2}\right)_{2}$ secondary antibodies, respectively, and nuclei counterstained with $1 \mu \mathrm{M}$ Hoechst 33342 . Images were acquired at $20 \mathrm{X}$ using the ImageXpress. An identification mask was overlaid onto each nucleus, and morphometric parameters, including (p)-Histone H3, EdU, and Ki-67 positivity, nuclear area, nuclear Hoechst 33342 intensity, and EdU intensity were quantitated using the MetaXpress v.6 Software (Molecular Devices) prior to single-cell analysis in $\mathrm{R}$. Cell cycle designations were assessed via a combined label-free method [101] with refinement using specific markers for proliferation/cell phase delineation [102]. Cells categorized into G1 were designated as $\mathrm{Ki}-67^{+} / \mathrm{EdU}^{-}$with a nuclear intensity less than the median of EdU ${ }^{+}$cells. Cells categorized into G2 were designated as $\mathrm{Ki}-67^{+} /$phospho-Histone $\mathrm{H} 3^{\text {Ser10 }}$ $-/ \mathrm{EdU}^{-}$with a nuclear intensity greater than the median of EdU ${ }^{+}$cells. G0 cells were designated as any cell Ki-67 ${ }^{-}$. pSAEC particle uptake resulted in non-specific binding of EdU and antibodies to intracellularly endocytosed particles, thus invalidating the method for this model.

\section{ROS measurement}

Beas-2B or pSAECs were plated with 5000 and 7500 cells per well, respectively, in clear-bottom, black-walled 96-well microplates and cultured 2 days prior to treatment with incinerated thermoplastics. At designated time points, thermoplastic- and menadione-treated cells were stained with $5 \mu \mathrm{M}$ of CellROX Green (ThermoFisher Scientific) and $1 \mu \mathrm{M}$ Hoechst 33342 in complete medium for $30 \mathrm{~min}$ under standard culture conditions and visualized using the ImageXpress. Nuclei were visualized using a standard DAPI filter set, while CellROX was visualized using a FITC filter set. Treatment with $100 \mu \mathrm{M}$ menadione (MP Biomedicals, LLC.; Solon, OH) for $60 \mathrm{~min}$ in complete growth medium was used as a positive ROS control prior to ROS assessment. After measurement/imaging, cells were fixed using $4 \%$ formaldehyde for $15 \mathrm{~min}$ at room temperature. A binary mask was generated based on nuclear Hoechst 33342 intensity from the DAPI channel and overlaid onto each nucleus for single cell identification. An intensity-based mask for the FITC channel was applied covering the nucleus and cytoplasm using the MetaXpress. Cell-specific masks were then quantitated for average intensity prior to comparisons.

\section{Genotoxicity}

Nuclear $\gamma \mathrm{H} 2 \mathrm{AX}$ positivity serves as a marker of stress induced by genotoxic agents [103]. After CellROX Green imaging, cells were probed using a 1:250 rabbit $\alpha-\gamma \mathrm{H} 2 \mathrm{AX}$ $\mathrm{mAb}$ (Cell Signaling Technology) in 1\% BSA in DPBS for $1 \mathrm{~h}$ at room temperature. $\gamma \mathrm{H} 2 \mathrm{AX}$ localization was tagged using an Alexa Fluor 647-conjugated goat $\alpha$-rabbit secondary antibody F(ab')2 fragments (Cell Signaling Technology), and nuclei counterstained with Hoechst 33342. Wells were imaged using the ImageXpress. Five hundred micrometre $\mathrm{H}_{2} \mathrm{O}_{2}$-treated cells (2 $\mathrm{h}$ prior to fixation) served as a positive control for $\gamma \mathrm{H} 2 \mathrm{AX}$ formation. A binary mask was generated based on nuclear Hoechst 33342 intensity from the DAPI channel and overlaid onto each nucleus for single cell identification. An intensity-based mask for the Cy5 channel was applied covering the nucleus using the MetaXpress. Cell-specific masks were then quantitated for average intensity prior to comparisons.

\section{Aryl hydrocarbon receptor Cytochrome P450 1 induction}

Cytochrome P450 1 isoforms (CYP1A and B) were assessed using a luminescence-based activity assay as per manufacturer's instructions (Promega Corporation; Madison, WI). Briefly, Beas-2B cells were plated in 96-well plates at a density of 5000 cells/well. $48 \mathrm{~h}$ post-treatment, cells were incubated with $100 \mu \mathrm{M}$ luciferin-CEE for $3 \mathrm{~h}$ under standard culture conditions. Thereafter, an aliquot of cell culture supernatant was abstracted and incubated in an equal volume of luciferase detection reagent at RT and quantitated using the Varioskan LUX multimodal plate reader (Thermo Fisher) with a $1.5 \mathrm{~s}$ integration time - cell-free medium served as the assay blank. $0.5 \mu \mathrm{M}$ $\mathrm{B}[\mathrm{a}] \mathrm{P}$ served as a control for CYP1 activity induction.

\section{Protein analysis}

Beas-2B cells were plated in 12-well microplates at a density of 62,000 cells per well $48 \mathrm{~h}$ prior to treatment. Cells were then treated with $0.5 \mu \mathrm{M} \mathrm{B}[\mathrm{a}] \mathrm{P}$ for $24 \mathrm{~h}$. Beas2B cells were lysed in RIPA buffer supplemented with 1 mM PMSF (Millipore-Sigma), $1 \mathrm{mM}$ Na-orthovanadate, and $1 \mathrm{X}$ proteinase inhibitor cocktail (Santa Cruz Biotechnologies; Dallas, TX). Whole cell lysate preparations were ultrasonicated for $5 \mathrm{~s}$ on ice, centrifuged at 13,000 $\mathrm{x} \mathrm{g}$ for $10 \mathrm{~min}$ at $4{ }^{\circ} \mathrm{C}$, and the supernatant moved to clean tubes for storage at $-80^{\circ} \mathrm{C}$. Lysate protein quantitation was performed via the BCA method.

Protein expression of whole cell lysates was evaluated using the ProteinSimple Wes (ProteinSimple; San Jose, CA) with total protein normalization as the loading control. Briefly, lysates were diluted to $1.0 \mu \mathrm{g} / \mu \mathrm{L}$ in $0.1 \mathrm{X}$ 
sample buffer supplied by ProteinSimple. All primary and secondary antibodies were purchased from Cell Signaling Technologies (Danvers, MA). Primary antibodies used to detect checkpoint induction were as followed: phospho-cdc2(Tyr15), phospho-Chk1(Ser345), which were diluted 1:50 in supplied antibody diluent. For chemiluminescent signal detection, primary antibodies were probed using a 1:100 anti-rabbit-HRP secondary antibody in supplied antibody diluent.

\section{Statistical analysis}

Regression modeling and statistical analyses were carried out using the R statistical program. Statistical comparisons were performed via Student's t-test. Dose-response modeling and associated $\mathrm{ED}_{50}$ derivations were attained using the "drc" package as described by Ritz et al. [104]. In the case of WST1, $\mathrm{ED}_{50}$ and $\mathrm{ED}_{110}$ values were derived from a modified non-linear five-parameter log-logistic (Cedergreen-Ritz-Streibig) model that accounts for hormetic response. Comparisons of $\mathrm{ED}_{50}$ were made via Student's t-test. Growth curves for deriving doubling time were modeled using the "growthcurves" package in R. All point estimates are the arithmetic mean of independent experiments with error bars indicating one standard error of the mean.

\section{Supplementary information}

Supplementary information accompanies this paper at https://doi.org/10. 1186/s12989-020-00371-1.

Additional file 1: Table S1. Medium-specific physicochemical properties for DLS measurement. Figure S1. SEM and EDX of incinerated thermoplastics. Figure S2. Enhanced darkfield microscopy of particle-only suspensions. Figure S3. Dose-response in Beas-2B using administered dose as the exposure metric. Figure S4. Comparison of $\Delta \psi_{\mathrm{m}}$ on two different analytical platforms. Figure S4. Comparison of $\Delta \psi_{\mathrm{m}}$ on two different analytical platforms. Figure S5. iNEC-induced intracellular ROS in pSAECs. Figure S6. Particle interference with $\mathrm{\gamma H} 2 \mathrm{AX}$ assessment in pSAECs. Figure S7. Endotoxin content and adsorption of incinerated thermoplastics. Figure S8. Lactate dehydrogenase interference testing in the presence of thermoplastics.

Additional file 2. Extended description of the methods has been included with additional details employed in this manuscript.

\section{Abbreviations}

aNF: Alpha-naphthoflavone; $\Delta \psi \mathrm{m}$ : Mitochondrial membrane potential; AEGM: Airway epithelial growth medium; B[a]P: Benzo[a]pyrene; CYP1: Cytochrome P450, family 1; DG: Distorted Grid; DMSO: Dimethyl sulfoxide; CNT: Carbon nanotube; CytoD: Cytochalasin D; DEP: Diesel exhaust particle; DSE $E_{c r}$ : Delivered critical sonication energy; EDM: Enhanced darkfield microscopy; EdU: 5-Ethynyl-2'-deoxyuridine; EDX: Energy dispersive x-ray spectroscopy; iNEC: Incinerated nano-enabled composite; LDH: Lactate dehydrogenase; MSW: Municipal solid waste; NEC: Nano-enabled composite; PAH: polycyclic aromatic hydrocarbon; PC: Polycarbonate; PC-

CNT: Polycarbonate with $3 \% \mathrm{w} / \mathrm{w}$ carbon nanotube; PDI: Polydispersity index; PI: Propidium iodide; PI-: Propidium iodide positivity adjusted for cell number; pSAEC: Primary small airway epithelial cell; PU: Polyurethane; PUCNT: polyurethane with $0.1 \% \mathrm{w} / \mathrm{w}$ carbon nanotube; ROS: Reactive oxygen species; SAGM: Small airway epithelial growth medium; SEM: Scanning electron microscopy; TEM: Transmission electron microscopy; VOC: Volatile organic chemical

\section{Acknowledgements}

The authors thank E. Kisin and N. Olgun for their critical review of this manuscript.

\section{Disclaimer}

The findings and conclusions in this report are those of the authors and do not necessarily represent the official position of the National Institute for Occupational Safety and Health, Centers for Disease Control and Prevention.

\section{Authors' contributions}

JPC designed and performed in vitro experimentation, performed statistical modeling and analysis, and wrote the manuscript. RCD designed in vitro experimentation and performed deposition modeling. TGK performed in vitro experimentation and assisted in writing the manuscript. DS generated the aerosols utilized in this manuscript. JJ assisted in the design and interpretation of the high-content imaging cell cycle analysis. SF performed and interpreted the electron microscopy analyses. RM performed the enhanced darkfield microscopy and assisted in interpretation of microscopy. TAS assisted in the design and analysis of high-content imaging experimentation. PD, YR, and LWR assisted in experimental design and oversaw execution of the study and manuscript preparation. The authors read and approved of the final manuscript.

\section{Funding}

This study was supported by a NIOSH/NTRC funding, and two NIH grants (R01-EB018857 and R01-ES022968).

Availability of data and materials

The data generated or analyzed during this study are included in this published article [and its supplementary information files] and are available from the corresponding author on reasonable request.

Ethics approval and consent to participate

Not applicable.

Consent for publication

Not applicable.

\section{Competing interests}

The authors declare that they have no competing interests.

\section{Author details}

${ }^{1}$ Health Effects Laboratory Division, National Institute for Occupational Safety and Health, Morgantown, WV, USA. ${ }^{2}$ Department of Pharmaceutical Sciences, West Virginia University, Morgantown, WV, USA. ${ }^{3}$ Department of Environmental Health, Harvard University, Boston, MA, USA.

Received: 18 March 2020 Accepted: 28 July 2020

Published online: 12 August 2020

\section{References}

1. Sastri VR. Plastics in medical devices: properties, requirements and applications. 2nd ed. Boston: Elsevier; 2010.

2. Ibeh CC. Thermoplastic materials: properties, manufacturing methods, and applications. Boca Raton: CRC Press; 2011.

3. Hepburn C. Polyurethane elastomers. 2nd ed. New York: Elsevier Science Publishers, LTD; 1992.

4. Gardea F, Lagoudas DC. Characterization of electrical and thermal properties of carbon nanotube/epoxy composites. Compos Part B Eng. 2014;56:611-20.

5. Li H, Zhong J, Meng J, Xian G. The reinforcement efficiency of carbon nanotubes/shape memory polymer nanocomposites. Compos Part B Eng. 2013;44(1):508-16

6. Bagotia N, Choudhary V, Sharma D. Studies on toughened polycarbonate/ multiwalled carbon nanotubes nanocomposites. Compos Part B Eng. 2017; 124:101-10.

7. Jindal P, Goyal M, Kumar N. Mechanical characterization of multiwalled carbon nanotubes-polycarbonate composites. Mater Des. 2014;54:864-8.

8. Liu S-P, S-S H, Yeh J-M, Pan K-W. Enhancement of surface and bulk mechanical properties of polycarbonate through the incorporation of raw MWNTs_-using the twin-screw extruder mixed technique. Int Commun Heat Mass Transfer. 2010;37(7):809-14. 
9. Pardo SG, Arboleda L, Ares A, García X, Dopico S, Abad MJ. Toughening strategies of carbon nanotube/polycarbonate composites with electromagnetic interference shielding properties. Polym Compos. 2013; 34(11):1938-49.

10. Pötschke P, Fornes T, Paul DR. Rheological behavior of multiwalled carbon nanotube/polycarbonate composites. Polymer. 2002;43(11):3247-55.

11. Larosa C, Patra N, Salerno M, Mikac L, Merijs Meri R, Ivanda M. Preparation and characterization of polycarbonate/multiwalled carbon nanotube nanocomposites. Beilstein J Nanotechnol. 2017;8:2026-31. https://doi.org/10. 3762/bjnano.8.203.

12. Chen $\mathbf{W}$, Tao X. Self-organizing alignment of carbon nanotubes in thermoplastic polyurethane. Macromol Rapid Commun. 2005;26(22):1763-7.

13. Khan U, May P, O'Neill A, Vilatela JJ, Windle AH, Coleman JN. Tuning the mechanical properties of composites from elastomeric to rigid thermoplastic by controlled addition of carbon nanotubes. Small. 2011;7(11): 1579-86.

14. Boonruksa P, Bello D, Zhang J, Isaacs JA, Mead JL, Woskie SR. Exposures to nanoparticles and fibers during injection molding and recycling of carbon nanotube reinforced polycarbonate composites. J Expo Sci Environ Epidemiol. 2017;27(4):379-90. https://doi.org/10.1038/jes.2016.26.

15. Wohlleben W, Meier MW, Vogel S, Landsiedel R, Cox G, Hirth S, et al. Elastic CNT-polyurethane nanocomposite: synthesis, performance and assessment of fragments released during use. Nanoscale. 2013;5(1):369-80.

16. Holder AL, Vejerano EP, Zhou X, Marr LC. Nanomaterial disposal by incineration. Environ Sci Process Impacts. 2013;15(9):1652-64.

17. U.S. EPA. National Overview: facts and figures on materials, wastes and recyclinghttps://www.epa.gov (N.D.). Accessed 25 June 2019; 2019.

18. Environmental Research \& Education Foundation. Analysis of MSW tipping fees, April 2017; 2017. Accessed 26 June 2019.

19. Elomaa M, Saharinen E. Polycyclic aromatic hydrocarbons (PAHs) in soot produced by combustion of polystyrene, polypropylene, and wood. J Appl Polym Sci. 1991:42(10):2819-24.

20. Li CT, Zhuang HK, Hsieh LT, Lee WJ, Tsao MC. PAH emission from the incineration of three plastic wastes. Environ Int. 2001;27(1):61-7.

21. Font R, Aracil I, Fullana A, Conesa JA. Semivolatile and volatile compounds in combustion of polyethylene. Chemosphere. 2004;57(7):615-27. https:// doi.org/10.1016/j.chemosphere.2004.06.020.

22. Hawley-Fedder R, Parsons M, Karasek F. Products obtained during combustion of polymers under simulated incinerator conditions: I. polyethylene. J Chromatogr A. 1984;314:263-73.

23. Hawley-Fedder R, Parsons M, Karasek F. Products obtained during combustion of polymers under simulated incinerator conditions: II. Polystyrene J Chromatogr A. 1984;315:201-10.

24. Hawley-Fedder R, Parsons M, Karasek F. Products obtained during combustion of polymers under simulated incinerator conditions: III. Polyvinyl chloride. J Chromatogr A. 1984;315:211-21.

25. Piao M, Chu S, Zheng M, Xu X. Characterization of the combustion products of polyethylene. Chemosphere. 1999;39(9):1497-512

26. Mitera J, Michal J. The combustion products of polymeric materials. III: GCMS analysis of the combustion products of polyethylene, polypropylene, polystyrene and polyamide. Fire Mater. 1985;9(3):111-6.

27. van Dell R, Mahle N, Hixson E. The effect of oxygen on the formation and destruction of the products of incomplete combustion from the combustion of polyethylene and o-dichlorobenzene. Combust Sci Technol. 1994;101(1-6):261-83.

28. Vejerano EP, Leon EC, Holder AL, Marr LC. Characterization of particle emissions and fate of nanomaterials during incineration. Environ Sci Nano. 2014; 1(2):133-43.

29. Singh D, Schifman LA, Watson-Wright C, Sotiriou GA, Oyanedel-Craver V, Wohlleben W, et al. Nanofiller presence enhances polycyclic aromatic hydrocarbon $(\mathrm{PAH})$ profile on nanoparticles released during thermal decomposition of Nano-enabled thermoplastics: potential environmental health implications. Environ Sci Technol. 2017;51(9):5222-32. https://doi.org/ 10.1021/acs.est.6b06448

30. Andersen MHG, Frederiksen M, Saber AT, Wils RS, Fonseca AS, Koponen IK, et al. Health effects of exposure to diesel exhaust in diesel-powered trains. Part Fibre Toxicol. 2019;16:21. https://doi.org/10.1186/s12989-019-0306-4.

31. Lin CC, Chen SJ, Huang KL, Lee WJ, Lin WY, Tsai JH, et al. PAHs, PAHinduced carcinogenic potency, and particle-extract-induced cytotoxicity of traffic-related nano/ultrafine particles. Environ Sci Technol. 2008; 42(11):4229-35.
32. Mordukhovich I, Beyea J, Herring AH, Hatch M, Stellman SD, Teitelbaum SL, et al. Vehicular traffic-related polycyclic aromatic hydrocarbon exposure and breast cancer incidence: the Long Island breast cancer study project (LIBCSP). Environ Health Perspect. 2016;124(1):30-8. https://doi.org/10.1289/ ehp.1307736.

33. Zhang $Y$, Zheng $H$, Zhang $L$, Zhang Z, Xing $X$, Qi S. Fine particle-bound polycyclic aromatic hydrocarbons (PAHs) at an urban site of Wuhan, Central China: characteristics, potential sources and cancer risks apportionment. Environ Pollut. 2019;246:319-27. https://doi.org/10.1016/j.envpol.2018.11.111.

34. Boffetta P, Jourenkova N, Gustavsson P. Cancer risk from occupational and environmental exposure to polycyclic aromatic hydrocarbons. Cancer Causes Control. 1997:8(3):444-72.

35. Brinchmann BC, Skuland T, Rambol MH, Szoke K, Brinchmann JE, Gutleb AC, et al. Lipophilic components of diesel exhaust particles induce proinflammatory responses in human endothelial cells through AhR dependent pathway(s). Part Fibre Toxicol. 2018;15(1):21. https://doi.org/10.1186/s12989018-0257-1.

36. Kawasaki S, Takizawa H, Takami K, Desaki M, Okazaki H, Kasama T, et al. Benzene-extracted components are important for the major activity of diesel exhaust particles: effect on interleukin-8 gene expression in human bronchial epithelial cells. Am J Respir Cell Mol Biol. 2001;24(4):419-26. https://doi.org/10.1165/ajrcmb.24.4.4085

37. Totlandsdal Al, Herseth Jl, Bølling AK, Kubátová A, Braun A, Cochran RE, et al. Differential effects of the particle core and organic extract of diese exhaust particles. Toxicol Lett. 2012;208(3):262-8.

38. Totlandsdal Al, Øvrevik J, Cochran RE, Herseth J-I, Bølling AK, Låg M, et al. The occurrence of polycyclic aromatic hydrocarbons and their derivatives and the proinflammatory potential of fractionated extracts of diesel exhaust and wood smoke particles. J Environ Sci Health A Tox Hazard Subst Environ Eng. 2014;49(4):383-96.

39. Lambrecht BN, Hammad $H$. The airway epithelium in asthma. Nat Med. 2012;18(5):684-92. https://doi.org/10.1038/nm.2737.

40. Brandt EB, Kovacic MB, Lee GB, Gibson AM, Acciani TH, Le Cras TD, et al. Diesel exhaust particle induction of IL-17A contributes to severe asthma. J Allergy Clin Immunol. 2013;132(5):1194-204. https://doi.org/10.1016/j.jaci. 2013.06.048.

41. Watson-Wright C, Singh D, Demokritou P. Toxicological implications of released particulate matter during thermal decomposition of Nano-enabled thermoplastics. Nanolmpact. 2017;5:29-40. https://doi.org/10.1016/j.impact. 2016.12.003.

42. Sotiriou GA, Singh D, Zhang F, Chalbot MG, Spielman-Sun E, Hoering L, et al. Thermal decomposition of nano-enabled thermoplastics: possible environmental health and safety implications. J Hazard Mater. 2016;305:8795. https://doi.org/10.1016/j.jhazmat.2015.11.001.

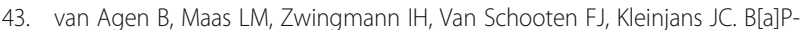
DNA adduct formation and induction of human epithelial lung cell transformation. Environ Mol Mutagen. 1997;30(3):287-92.

44. Totlandsdal Al, Cassee FR, Schwarze P, Refsnes M, Lag M. Diesel exhaust particles induce CYP1A1 and pro-inflammatory responses via differential pathways in human bronchial epithelial cells. Part Fibre Toxicol. 2010;7:41. https://doi.org/10.1186/1743-8977-7-41.

45. Øvrevik J, Arlt VM, Øya E, Nagy E, Mollerup S, Phillips DH, et al. Differential effects of nitro-PAHs and amino-PAHs on cytokine and chemokine responses in human bronchial epithelial BEAS-2B cells. Toxicol Appl Pharmacol. 2010;242(3):270-80. https://doi.org/10.1016/j.taap.2009.10.017.

46. Pohjola SK, Lappi M, Honkanen M, Rantanen L, Savela K. DNA binding of polycyclic aromatic hydrocarbons in a human bronchial epithelial cell line treated with diesel and gasoline particulate extracts and benzo[a]pyrene. Mutagenesis. 2003;18(5):429-38. https://doi.org/10.1093/mutage/geg021.

47. Lin $\mathrm{P}$, Chang $Y C$, Chen $\mathrm{CH}$, Yang WJ, Cheng YH, Chang LW. A comparative study on the effects of 2,3,7,8,-tetrachlorodibenzo-p-dioxin polychlorinated biphenyl126 and estrogen in human bronchial epithelial cells. Toxicol Appl Pharmacol. 2004;195(1):83-91. https://doi.org/10.1016/j.taap.2003.11.001.

48. Zhao B, Degroot DE, Hayashi A, He G, Denison MS. CH223191 is a ligandselective antagonist of the ah (dioxin) receptor. Toxicol Sci. 2010;117(2):393403. https://doi.org/10.1093/toxsci/kfq217.

49. Wawer MJ, Li K, Gustafsdottir SM, Ljosa V, Bodycombe NE, Marton MA, et al. Toward performance-diverse small-molecule libraries for cell-based phenotypic screening using multiplexed high-dimensional profiling. Proc Natl Acad Sci U S A. 2014;111(30):10911-6. https://doi.org/10.1073/pnas. 1410933111. 
50. Baulig A, Garlatti M, Bonvallot V, Marchand A, Barouki R, Marano F, et al. Involvement of reactive oxygen species in the metabolic pathways triggered by diesel exhaust particles in human airway epithelial cells. Am J Physiol Lung Cell Mol Physiol. 2003;285(3):L671-L9. https://doi.org/10.1152/ ajplung.00419.2002.

51. Savary CC, Bellamri N, Morzadec C, Langouet S, Lecureur V, Vernhet L. Long term exposure to environmental concentrations of diesel exhaust particles does not impact the phenotype of human bronchial epithelial cells. Toxicol In Vitro. 2018;52:154-60. https://doi.org/10.1016/j.tiv.2018.06.014.

52. Courcot E, Leclerc J, Lafitte JJ, Mensier E, Jaillard S, Gosset P, et al. Xenobiotic metabolism and disposition in human lung cell models: comparison with in vivo expression profiles. Drug Metab Dispos. 2012; 40(10):1953-65. https://doi.org/10.1124/dmd.112.046896.

53. Garcia-Canton C, Minet E, Anadon A, Meredith C. Metabolic characterization of cell systems used in in vitro toxicology testing: lung cell system BEAS-2B as a working example. Toxicol In Vitro. 2013;27(6):1719-27. https://doi.org/ 10.1016/j.tiv.2013.05.001.

54. OECD. 473: in vitro mammalian chromosome aberration test. OECD guidelines for the testing of chemicals; 1997. p. 4.

55. Uppstad H, Ovrebo S, Haugen A, Mollerup S. Importance of CYP1A1 and CYP1B1 in bioactivation of benzo[a]pyrene in human lung cell lines. Toxicol Lett. 2010;192(2):221-8. https://doi.org/10.1016/j.toxlet.2009.10.025.

56. Nikolova T, Dvorak M, Jung F, Adam I, Kramer E, Gerhold-Ay A, et al. The gammaH2AX assay for genotoxic and nongenotoxic agents: comparison of H2AX phosphorylation with cell death response. Toxicol Sci. 2014;140(1): 103-17. https://doi.org/10.1093/toxsci/kfu066.

57. Rogakou EP, Pilch DR, Orr AH, Ivanova VS, Bonner WM. DNA doublestranded breaks induce histone H2AX phosphorylation on serine 139. J Biol Chem. 1998;273(10):5858-68. https://doi.org/10.1074/jbc.273.10.5858.

58. Baulig A, Sourdeval M, Meyer M, Marano F, Baeza-Squiban A. Biological effects of atmospheric particles on human bronchial epithelial cells. Comparison with diesel exhaust particles. Toxicology Vitro. 2003b;17(5-6): 567-73. https://doi.org/10.1016/s0887-2333(03)00115-2.

59. Boland S, Baeza-Squiban A, Fournier T, Houcine O, Gendron MC, Chevrier M, et al. Diesel exhaust particles are taken up by human airway epithelial cells in vitro and alter cytokine production. Am J Physiol. 1999;276(4):L604-L13. https://doi.org/10.1152/ajplung.1999.276.4.L604.

60. Lesniak A, Campbell A, Monopoli MP, Lynch I, Salvati A, Dawson KA. Serum heat inactivation affects protein corona composition and nanoparticle uptake. Biomater. 2010;31(36):9511-8. https://doi.org/10.1016/j.biomaterials. 2010.09.049

61. Lesniak A, Fenaroli F, Monopoli MP, Aberg C, Dawson KA, Salvati A. Effects of the presence or absence of a protein corona on silica nanoparticle uptake and impact on cells. ACS Nano. 2012;6(7):5845-57. https://doi.org/10. $1021 / \mathrm{nn} 300223 \mathrm{w}$

62. dos Santos T, Varela J, Lynch I, Salvati A, Dawson KA. Effects of transport inhibitors on the cellular uptake of carboxylated polystyrene nanoparticles in different cell lines. PLoS One. 2011;6(9):e24438. https://doi.org/10.1371/ journal.pone.0024438.

63. Bouillard JX, R'Mili B, Moranviller D, Vignes A, Le Bihan O, Ustache A, et al. Nanosafety by design: risks from nanocomposite/nanowaste combustion. Nanopart Res. 2013;15(4):1519.

64. Pang LS, Saxby JD, Chatfield SP. Thermogravimetric analysis of carbon nanotubes and nanoparticles. J Phys Chem. 1993;97(27):6941-2.

65. Roes L, Patel MK, Worrell E, Ludwig C. Preliminary evaluation of risks related to waste incineration of polymer nanocomposites. Sci Total Environ. 2012; 417-418:76-86. https://doi.org/10.1016/j.scitotenv.2011.12.030.

66. Zhu M, Nie G, Meng H, Xia T, Nel A, Zhao Y. Physicochemical properties determine nanomaterial cellular uptake, transport, and fate. Acc Chem Res. 2013;46(3):622-31. https://doi.org/10.1021/ar300031y.

67. Lai X, Wei Y, Zhao H, Chen S, Bu X, Lu F, et al. The effect of Fe2O3 and ZnO nanoparticles on cytotoxicity and glucose metabolism in lung epithelial cells. J Appl Toxicol. 2015;35(6):651-64. https://doi.org/10.1002/jat.3128.

68. Park EJ, Lee $\mathrm{GH}$, Yoon C, Jeong U, Kim Y, Cho MH, et al. Biodistribution and toxicity of spherical aluminum oxide nanoparticles. J Appl Toxicol. 2016; 36(3):424-33. https://doi.org/10.1002/jat.3233.

69. Takeshita K, Ogawa HI, Maeda T. Structural chromosome aberrations cause swelling of the nucleus. Genes Environ. 2016:38:22. https://doi.org/10.1186/ s41021-016-0047-7.

70. Khoury L, Zalko D, Audebert M. Complementarity of phosphorylated histones $\mathrm{H} 2 \mathrm{AX}$ and $\mathrm{H} 3$ quantification in different cell lines for genotoxicity screening. Arch Toxicol. 2016;90(8):1983-95. https://doi.org/10.1007/s00204015-1599-1.

71. Bryce SM, Bemis JC, Mereness JA, Spellman RA, Moss J, Dickinson D, et al. Interpreting in vitro micronucleus positive results: simple biomarker matrix discriminates clastogens, aneugens, and misleading positive agents. Environ Mol Mutagen. 2014;55(7):542-55. https://doi.org/10.1002/em.21868.

72. Vaziri C, Faller DV. A benzo[a]pyrene-induced cell cycle checkpoint resulting in p53-independent G1 arrest in 3T3 fibroblasts. J Biol Chem. 1997;272(5): 2762-9. https://doi.org/10.1074/jbc.272.5.2762.

73. Øya E, Øvrevik J, Arlt VM, Nagy E, Phillips DH, Holme JA. DNA damage and DNA damage response in human bronchial epithelial BEAS-2B cells following exposure to 2-nitrobenzanthrone and 3-nitrobenzanthrone: role in apoptosis. Mutagenesis. 2011;26(6):697-708. https://doi.org/10.1093/mutage/ ger035.

74. Garcia-Canton C, Anadon A, Meredith C. gammaH2AX as a novel endpoint to detect DNA damage: applications for the assessment of the in vitro genotoxicity of cigarette smoke. Toxicol In Vitro. 2012;26(7):1075-86. https:// doi.org/10.1016/j.tiv.2012.06.006.

75. Wu J, Shi Y, Asweto CO, Feng L, Yang X, Zhang Y, et al. Co-exposure to amorphous silica nanoparticles and benzo[a]pyrene at low level in human bronchial epithelial BEAS-2B cells. Environ Sci Pollut Res Int. 2016;23(22): 23134-44. https://doi.org/10.1007/s11356-016-7559-3.

76. Zhu W, Cromie MM, Cai Q, Lv T, Singh K, Gao W. Curcumin and vitamin E protect against adverse effects of benzo[a]pyrene in lung epithelial cells. PLoS One. 2014:9(3):e92992. https://doi.org/10.1371/journal.pone.0092992.

77. Eudey TL. Statistical considerations in DNA flow cytometry. Stat Sci. 1996; 11(4):320-34.

78. Brown MR, Summers HD, Rees P, Smith PJ, Chappell SC, Errington RJ. Flowbased cytometric analysis of cell cycle via simulated cell populations. PLoS Comput Biol. 2010;6(4):e1000741. https://doi.org/10.1371/journal.pcbi. 1000741.

79. Blackford AN, Jackson SP. ATM, ATR, and DNA-PK: the trinity at the heart of the DNA damage response. Mol Cell. 2017;66(6):801-17. https://doi.org/10. 1016/.j.molcel.2017.05.015.

80. Caino MC, Oliva JL, Jiang H, Penning TM, Kazanietz MG. Benzo[a]pyrene-7,8dihydrodiol promotes checkpoint activation and G2/M arrest in human bronchoalveolar carcinoma H358 cells. Mol Pharmacol. 2007;71(3):744-50. https://doi.org/10.1124/mol.106.032078.

81. Lehman TA, Modali R, Boukamp P, Stanek J, Bennett WP, Welsh JA, et al. p53 mutations in human immortalized epithelial cell lines. Carcinogenesis. 1993;14(5):833-9. https://doi.org/10.1093/carcin/14.5.833.

82. Lin AB, McNeely SC, Beckmann RP. Achieving precision death with cell-cycle inhibitors that target DNA replication and repair. Clin Cancer Res. 2017; 23(13):3232-40. https://doi.org/10.1158/1078-0432.ccr-16-0083.

83. Parker LL, Piwnica-Worms H. Inactivation of the p34cdc2-cyclin B complex by the human WEE1 tyrosine kinase. Science (New York, NY). 1992; 257(5078):1955-7. https://doi.org/10.1126/science.1384126.

84. Zhao H, Piwnica-Worms H. ATR-mediated checkpoint pathways regulate phosphorylation and activation of human Chk1. Mol Cell Biol. 2001;21(13): 4129-39. https://doi.org/10.1128/mcb.21.13.4129-4139.2001.

85. Zhu H, Zhang L, Wu S, Teraishi F, Davis JJ, Jacob D, et al. Induction of Sphase arrest and p21 overexpression by a small molecule 2[[3-(2,3dichlorophenoxy)propyl] amino]ethanol in correlation with activation of ERK. Oncogene. 2004;23(29):4984-92. https://doi.org/10.1038/sj.onc.1207645.

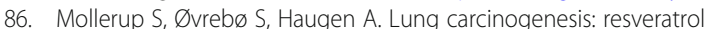
modulates the expression of genes involved in the metabolism of PAH in human bronchial epithelial cells. Int J Cancer. 2001;92(1):18-25.

87. Liu X, Ji R, Shi Y, Wang F, Chen W. Release of polycyclic aromatic hydrocarbons from biochar fine particles in simulated lung fluids: implications for bioavailability and risks of airborne aromatics. Sci Total Environ. 2019;655:1159-68. https://doi.org/10.1016/j.scitotenv. 2018.11.294.

88. Gerde P, Muggenburg BA, Lundborg M, Dahl AR. The rapid alveolar absorption of diesel soot-adsorbed benzo[a]pyrene: bioavailability, metabolism and dosimetry of an inhaled particle-borne carcinogen. Carcinogenesis. 2001;22(5):741-9. https://doi.org/10.1093/carcin/22.5.741.

89. Chang H, Chang LW, Cheng YH, Tsai WT, Tsai MX, Lin P. Preferential induction of CYP1A1 and CYP1B1 in CCSP-positive cells. Toxicological Sci. 2006;89(1):205-13. https://doi.org/10.1093/toxsci/kfj025.

90. Berridge M, Tan A. Trans-plasma membrane electron transport: a cellular assay for NADH-and NADPH-oxidase based on extracellular, superoxide- 
mediated reduction of the sulfonated tetrazolium salt WST-1. Protoplasma. 1998;205(1-4):74-82.

91. Verma N, Pink M, Boland S, Rettenmeier AW, Schmitz-Spanke S. Benzo[a]pyrene-induced metabolic shift from glycolysis to pentose phosphate pathway in the human bladder cancer cell line RT4. Sci Rep. 2017;7(1):9773. https://doi.org/10.1038/s41598-017-09936-1.

92. Zhu A, Romero R, Petty HR. An enzymatic colorimetric assay for glucose-6phosphate. Anal Biochem. 2011;419(2):266-70. https://doi.org/10.1016/j.ab. 2011.08.037.

93. Pal AK, Bello D, Cohen J, Demokritou P. Implications of in vitro dosimetry on toxicological ranking of low aspect ratio engineered nanomaterials, Nanotoxicology. 2015;9(7):871-85. https://doi.org/10.3109/17435390.2014. 986670.

94. Pal AK, Watson CY, Pirela SV, Singh D, Chalbot MC, Kavouras I, et al. Linking exposures of particles released from Nano-enabled products to toxicology: an integrated methodology for particle sampling, extraction, dispersion, and dosing. Toxicol Sci. 2015;146(2):321-33. https://doi.org/10.1093/toxsci/kfv095.

95. Singh D, Sotiriou GA, Zhang F, Mead J, Bello D, Wohlleben W, et al. End-oflife thermal decomposition of nano-enabled polymers: effect of nanofiller loading and polymer matrix on by-products. Environ Sci Nano. 2016;3(6): 1293-305.

96. Sotiriou GA, Singh D, Zhang F, Wohlleben W, Chalbot MG, Kavouras IG, et al. An integrated methodology for the assessment of environmental health implications during thermal decomposition of nano-enabled products. Environ Sci Nano. 2015;2(3):262-72. https://doi.org/10.1039/c4en00210e.

97. DeLoid GM, Cohen JM, Pyrgiotakis G, Demokritou P. Preparation, characterization, and in vitro dosimetry of dispersed, engineered nanomaterials. Nat Protoc. 2017;12(2):355-71. https://doi.org/10.1038/nprot. 2016.172 .

98. Neun BW, Binskaya AN, Dobrovolskaia MA. NCL method STE-1.1: detection and quantification of gram negative bacterial endotoxin contamination in nanoparticle formulations by end point chromogenic LAL assay. Version 1.3. Frederick: Nanotechnology Characterization Laboratory. Frederick National Laboratory for Cancer Research, National Cancer Institute; 2015.

99. Cerveira JF, Sanchez-Arago M, Urbano AM, Cuezva JM. Short-term exposure of nontumorigenic human bronchial epithelial cells to carcinogenic chromium(VI) compromises their respiratory capacity and alters their bioenergetic signature. FEBS Open Bio. 2014;4:594-601. https://doi.org/10. 1016/j.fob.2014.06.006.

100. Salic A, Mitchison TJ. A chemical method for fast and sensitive detection of DNA synthesis in vivo. Proc Natl Acad Sci U S A. 2008;105(7):2415-20. https://doi.org/10.1073/pnas.0712168105.

101. Blasi T, Hennig H, Summers HD, Theis FJ, Cerveira J, Patterson JO, et al. Label-free cell cycle analysis for high-throughput imaging flow cytometry. Nat Commun. 2016;7:10256. https://doi.org/10.1038/ncomms10256.

102. Solovjeva LV, Demin SJ, Pleskach NM, Kuznetsova MO, Svetlova MP. Characterization of telomeric repeats in metaphase chromosomes and interphase nuclei of Syrian hamster fibroblasts. Mol Cytogenet. 2012;5(1):37. https://doi.org/10.1186/1755-8166-5-37.

103. Takeiri A, Matsuzaki K, Motoyama S, Yano M, Harada A, Katoh C, et al. Highcontent imaging analyses of gammaH2AX-foci and micronuclei in TK6 cells elucidated genotoxicity of chemicals and their clastogenic/aneugenic mode of action. Genes Environ. 2019;41:4. https://doi.org/10.1186/s41021-0190117-8.

104. Ritz C, Baty F, Streibig JC, Gerhard D. Dose-response analysis using R. PLoS One. 2015;10(12):e0146021. https://doi.org/10.1371/journal.pone.0146021.

\section{Publisher's Note}

Springer Nature remains neutral with regard to jurisdictional claims in published maps and institutional affiliations.

Ready to submit your research? Choose BMC and benefit from:

- fast, convenient online submission

- thorough peer review by experienced researchers in your field

- rapid publication on acceptance

- support for research data, including large and complex data types

- gold Open Access which fosters wider collaboration and increased citations

- maximum visibility for your research: over $100 \mathrm{M}$ website views per year

At $\mathrm{BMC}$, research is always in progress.

Learn more biomedcentral.com/submissions 